Studies on the role of disturbed $\mathrm{Ca}^{2+}$ homeostasis in the pathomechanism of the cardiac effects of experimental diabetes using conventional and novel experimental techniques

PhD Thesis

János Prorok, MSc

Department of Pharmacology \& Pharmacotherapy

Albert Szent-Györgyi Medical Center

University of Szeged

Szeged, Hungary 


\section{PUBLICATION LIST}

\section{a.) Published literature related to $\mathrm{PhD}$ topic}

I. Prorok J, Kovács PP, Kristóf AA, Nagy N, Tombácz D, Tóth JS, Ordög B, Jost N, Virág L, Papp JG, Varró A, Tóth A, Boldogkoi Z. Herpesvirus-mediated delivery of a genetically encoded fluorescent $\mathrm{Ca}\left({ }^{2+}\right)$ sensor to canine cardiomyocytes. J Biomed Biotechnol. 2009;2009:361795. IF: 1.770

II. Birinyi P, Tóth A, Jóna I, Acsai K, Almássy J, Nagy N, Prorok J, Gherasim I, Papp Z, Hertelendi Z, Szentandrássy N, Bányász T, Fülöp F, Papp JG, Varró A, Nánási PP, Magyar J. The $\mathrm{Na}^{+} / \mathrm{Ca}^{2+}$ exchange blocker SEA0400 fails to enhance cytosolic $\mathrm{Ca}^{2+}$ transient and contractility in canine ventricular cardiomyocytes. Cardiovasc Res. 2008 Jun 1;78(3):476-84. IF: $\mathbf{5 . 9 4 7}$

\section{b.) Other studies}

I. Nagy N, Szuts V, Horváth Z, Seprényi G, Farkas AS, Acsai K, Prorok J, Bitay M, Kun A, Pataricza J, Papp JG, Nánási PP, Varró A, Tóth A. Does small-conductance calcium-activated potassium channel contribute to cardiac repolarization? J Mol Cell Cardiol. 2009 Nov;47(5):656-63. Epub 2009 Jul 24.IF.: 5,05

II. Pecze L, Szabó K, Széll M, Jósvay K, Kaszás K, Kúsz E, Letoha T, Prorok J, Koncz I, Tóth A, Kemény L, Vizler C, Oláh Z. Human keratinocytes are vanilloid resistant. PLoS One. 2008;3(10):e3419. Epub 2008 Oct 14. IF.: 0 


\section{c.) Conference presentations related to $\mathrm{PhD}$ topic}

I. Prorok J, Tóth A, Iost N, Kovács PP, Kristóf AA, Tombácz D, Tóth J, Ördög B, Virág L, Papp JG, Varró A, Boldogkői Z.. Herpesvirus-mediated delivery of genetically encoded fluorescent $\mathrm{Ca}^{2+}$ sensor to adult canine cardiomyocytes. 32nd Meeting of the European Working Group on Cardiac and Cellular Electrophysiology, Madrid, Spain. 2008

II. Prorok J., Nagy N., Kormos A., Acsai K., Papp Gy., Varró A., Tóth A. 2008 The effect of the NCX inhibitor SEA0400 is intracellular $\mathrm{Ca}^{2+}$ level dependent in canine ventricular myocytes. Cardiol. Hungarica, 2008, 38. Suppl.B: B20

III. Prorok J, Jost N, Kovács PP. Kristóf A, Tóth A, Ördög B, Boldogkői Z. 2007. Gene transfer into cardiac muscle cells with herpes virus. Cardiologica Hungarica, 37: Suppl A, A24. 


\section{ABREVATIONS AND ACRONYSM}

$\left[\mathrm{Ca}^{2+}\right]_{\mathrm{i}}$ : intracellular $\mathrm{Ca}^{2+}$

AAVs: adeno associated viruses

AdVs: adenoviruses

AP: action potential

ATP: adenosine-triphosphate

BFP: blue fluorescent protein

CaM: $\mathrm{Ca}^{2+}$-sensitive module: a hybrid of a $\mathrm{Ca}^{2+}$ binding domain of calmodulin

CaM: calmodulin

CaMKII: $\mathrm{Ca}^{2+}$-dependent calmodulin-kinase II

cAMP: cyclic adenosine-monophosphate

CAR: coxsackie adenovirus receptor

CFP: cyan fluorescent protein

CICR: $\mathrm{Ca}^{2+}$ induced $\mathrm{Ca}^{2+}$ release

ECC: excitation contraction coupling

FRET: Fluorescence resonance energy transfer

GECIs: genetically encoded calcium indicators

GFP: green fluorescent protein

$\mathrm{I}_{\mathrm{CaL}}$ : L-type $\mathrm{Ca}^{2+}$ current

KB: Kraft Brühe solution

KH: Krebs-Henseleit solution

M13: myosin light chain kinase peptide

NCX: $\mathrm{Na}^{+}-\mathrm{Ca}^{2+}$ exchanger

PMCA sarcolemmal Ca2+ ATPase

PRV: pseudorabies virus

RVs: retroviruses

RyR: ryanodine receptor

SERCA: sarcoplasmic reticulum $\mathrm{Ca}^{2+}$ ATPase

TnC: troponin C

YFP: yellow fluorescent protein 


\section{TABLE OF CONTENTS}

1. SUMMARY

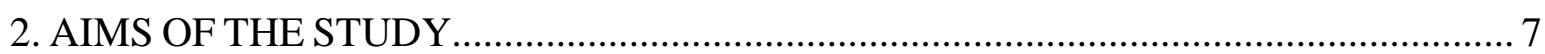

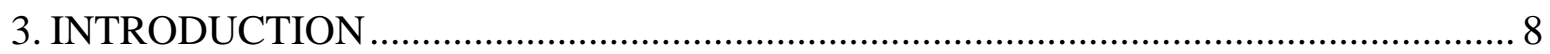

3.1 Physiology of $\mathrm{Ca}^{2+}$ handling in the cardiac myocytes ............................................. 8

3.2 Altered $\mathrm{Ca}^{2+}$ handling in diabetes......................................................................... 10

3.3 Optical measurement of the intracellular calcium concentration ............................. 11

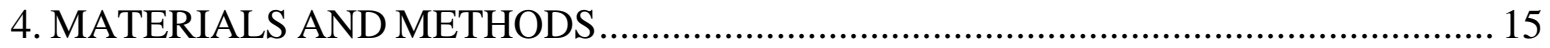

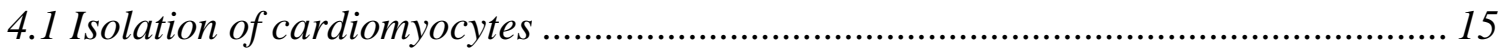

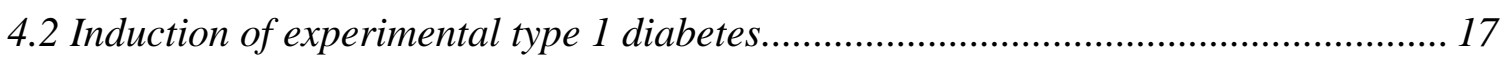

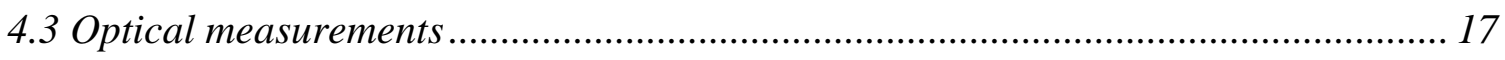

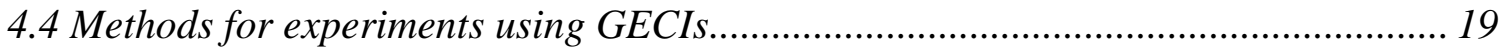

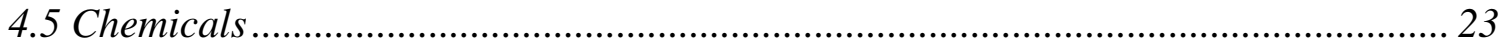

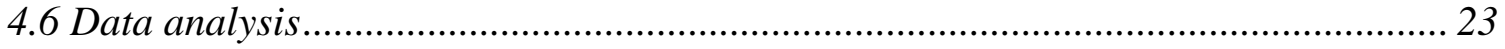

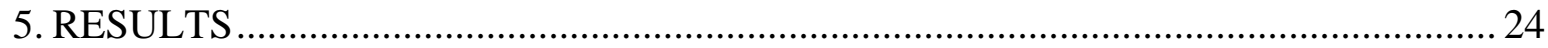

5.1 Characterization of the NCX inhibiting effect of SEA0400 in canine cardiomyocytes

5.2 Evaluation of intracellular $\mathrm{Ca}^{2+}$ changes during type 1 diabetes in rabbit myocytes 25

5.3 Herpesvirus-mediated delivery of a genetically encoded fluorescent $\mathrm{Ca}^{2+}$ sensor to

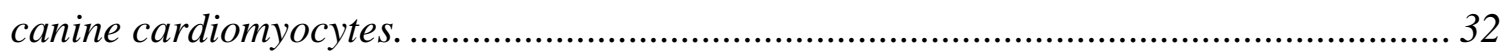

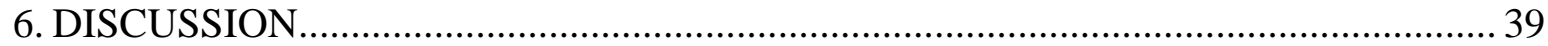

$6.1 \mathrm{New}$ challenges in the field of $\mathrm{Ca}^{2+}$ signaling research ........................................... 39

6.2 Effect of SEAO4OO on caffeine induced $\mathrm{Ca}^{2+}$ transients in canine cardiomyocytes:

validation of SEA0400 as a tool to study the $\mathrm{Ca}^{2+}$ homeostasis ....................................... 39

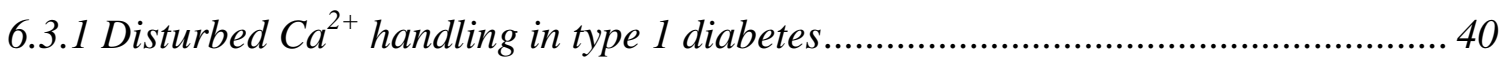

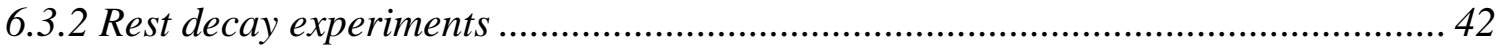

6.4 Delivery of troponeon to cultured cardiomyocytes ................................................... 43

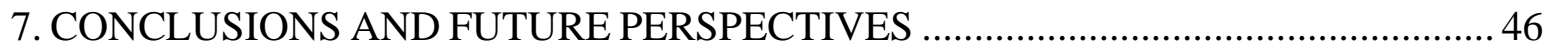

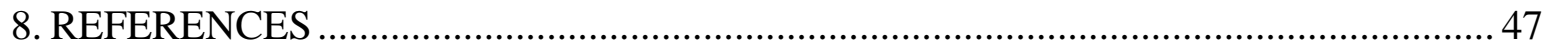

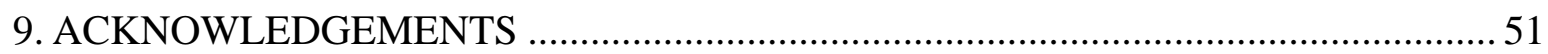

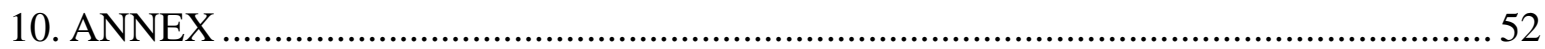




\section{SUMMARY}

The $\mathrm{Na}^{+} / \mathrm{Ca}^{2+}$ exchanger (NCX) plays a crucial role in cardiac electrophysiology via maintaining ionic distributions between the cytoplasm and the extracellular space, shaping the action potential and modulating the contractile activity of the heart via tight regulation of the cytoplasmic $\left[\mathrm{Ca}^{2+}\right]$. Since the NCX is the primary transporter to extrude $\mathrm{Ca}^{2+}$ from the cells, both the $\mathrm{Ca}^{2+}$ content of the cardiomyocytes and magnitude and kinetics of the intracellular $\mathrm{Ca}^{2+}$-transient during action potential are highly dependent on its expression level and functional activity. In spite of its critical function, a relatively selective pharmacological NCX inhibitor (SEA0400) has only recently become available, offering yet unexplored novel possibilities in studying NCX function and malfunction. In our first experimental study we aimed to evaluate the effects of selective, partial NCX inhibition by SEA0400 on $\mathrm{Ca}^{2+}$ handling in isolated canine ventricular myocytes.

Since the origin and progression of the pathomechanisms, leading to diabetes-induced cardiomyopathy, are poorly explored, monitoring diabetes induced changes in intracellular $\mathrm{Ca}^{2+}$ handling in cardiomyocytes in various functional states may help us to improve our rather limited understanding of the pathophysiology of diabetes-associated heart diseases. This improvement, in turn, may open much needed novel therapeutic avenues for more effective prevention and early treatment of cardiac complications in diabetic patients. In our second study we aimed to investigate in an experimental animal model of Type 1 diabetes the putative perturbations in NCX function, by monitoring shifts in intracellular $\left[\mathrm{Ca}^{2+}\right]$, following the application of the selective NCX inhibitor SEA0400.

The final part of the present thesis describes a promising methodological work. Virusmediated gene transfer has recently become an important tool for introduction of recombinant genes into cardiomyocytes, offering the potential to treat both rare and common cardiac disorders. In our third study we have developed a novel, pseudorabies virus vector (PRV)based technique, which enables the targeted delivery of genetically encoded activity sensors into primary culture of isolated adult canine cardiomyocytes. This system has several advantageous features: 1) the virus enters the cells without destroying the intact physiological properties of the cells for a prolonged period; 2) the virus had no effect on the observed physiological properties. We have shown for the first time, that novel herpesvirus-based vectors can efficiently transduce genes into non-dividing cardiac myocytes, offering an alternative approach for gene transfer in this fastidious experimental object. 


\section{AIMS OF THE STUDY}

Unfortunately, however, there is no single best technique/method with which one can measure local intracellular $\left[\mathrm{Ca}^{2+}\right]$. While each method for analyzing $\mathrm{Ca}^{2+}$ activity has certain advantages over the others, each also suffers significant drawbacks. Our first goal was to establish a simple, reliable experimental system for the measurement of $\mathrm{Ca}^{2+}$ activity, which can provide us with more detailed insights into the $\mathrm{Ca}^{2+}$ housekeeping of cardiomyocytes under physiological and pathophysiological conditions. Our second goal was to develop an alternative approach for $\mathrm{Ca}^{2+}$ measurement and to test the applicability of the novel technique in the experimental settings of basic cardiac electrophysiology by paying particular attention to the combination of genetically encoded $\mathrm{Ca}^{2+}$-sensors with virus-based gene transfer.

In summary, the primary goals of the experimental work summarized in this thesis were, as follows:

1. To directly validate the NCX inhibitory effect of SEA0400 on caffeine-induced $\mathrm{Ca}^{2+}$ transients in canine cardiac myocytes with undisturbed $\mathrm{Ca}^{2+}$ handling.

2. To investigate the role of $\mathrm{NCX}$ in pathological shifts of $\mathrm{Ca}^{2+}$ handling in cardiac myocytes isolated from rabbits with experimental Type 1 diabetes.

3. To develop a novel, pseudorabies virus (PRV)-based method for targeted delivery of foreign genes into isolated adult cardiomyocytes in primary culture to facilitate future investigations of subcellular events underlying the patomechanism of the cardiac effects of diabetes 


\section{INTRODUCTION}

At the cellular level, a wide range of physiological processes, as well as a number of pathomechanisms are also reflected in substantial changes of the intracellular ion milieu. Calcium ion $\left(\mathrm{Ca}^{2+}\right)$ is a ubiquitous intracellular second messenger, involved in the regulation of a plethora of highly diverse cellular functions such as fertilization, electric signaling, contraction, secretion, memory, gene transcription and programmed cell death.

Because of the importance of $\mathrm{Ca}^{2+}$ in biology, numerous techniques/methods for analyzing the mechanisms of cellular and/or subcellular $\mathrm{Ca}^{2+}$ activity have been established. Since the first attempt to monitor intracellular $\mathrm{Ca}^{2+}$ dynamics by Tsien et al. [1] fluorescence based $\mathrm{Ca}^{2+}$ signal research has undergone a tremendous development, and is still being improved. In the first part of my thesis I summarize the theoretical background, as well, as the substantial limitations of the conventional $\mathrm{Ca}^{2+}$-sensitive dye-based fluorescence technique widely used to (semi)quantitatively evaluate shifts in intracellular $\mathrm{Ca}^{2+}$ levels and distribution and also discuss the principles of promising new enhancements of the classical methodology.

\subsection{Physiology of $\mathrm{Ca}^{2+}$ handling in the cardiac myocytes}

From the ions involved in the intricate workings of the heart, calcium is considered perhaps to be the most important. $\mathrm{Ca}^{2+}$ is crucial to the complex process called excitationcontraction coupling that enables the heart to contract and relax. In order to understand the physiological regulation of the mechanical activity of the heart, it is important to describe in details, how calcium is transported between the various intracellular compartments of the cardiomyocyte during activation and termination of the contraction

During the cardiac action potential (AP), $\mathrm{Ca}^{2+}$ enters the cell via depolarizationactivated (primarily L-type) $\mathrm{Ca}^{2+}$ channels as an inward current $\left(\mathrm{I}_{\mathrm{Ca}}\right)$, which substantially contributes to shaping the plateau phase of the AP.

The primary $\mathrm{Ca}^{2+}$ entry triggers a secondary $\mathrm{Ca}^{2+}$ release from the sarcoplasmic reticulum (SR). Each junction between the sarcolemma (T-tubule and surface) and SR, where 10-25 L-type $\mathrm{Ca}^{2+}$ channels and 100-200 ryanodine receptors (RyRs) are clustered, constitutes a local $\mathrm{Ca}^{2+}$ signaling complex. When an L-type Ca channel opens, local $\left[\mathrm{Ca}^{2+}\right]_{\mathrm{i}}$ rises and $\mathrm{Ca}^{2+}$ is released from the sarcoplasmic reticulum (SR) via the RyRs during the course of a process called $\mathrm{Ca}^{2+}$-induced $\mathrm{Ca}^{2+}$ release [2]. In this phase of the action potential, the $\mathrm{Na}^{+} / \mathrm{Ca}^{2+}$ exchanger can also contribute to the $\mathrm{Ca}^{2+}$ influx (reverse mode operation) since the membrane potential is positive and the intracellular $\mathrm{Ca}^{2+}$ level is low. However, when - 
due to the $\mathrm{Ca}^{2+}$ induced release of $\mathrm{Ca}^{2+}$ from the sarcoplasmic reticulum - the intracellular $\mathrm{Ca}^{2+}$ level increases at the beginning of the intracellular " $\mathrm{Ca}^{2+}$ transient", the $\mathrm{Na}^{+} / \mathrm{Ca}^{2+}$ exchanger turns into forward mode operation, thereby contributing to the extrusion of $\mathrm{Ca}^{2+}$ from the cell (Fig. 1) [3, 4]

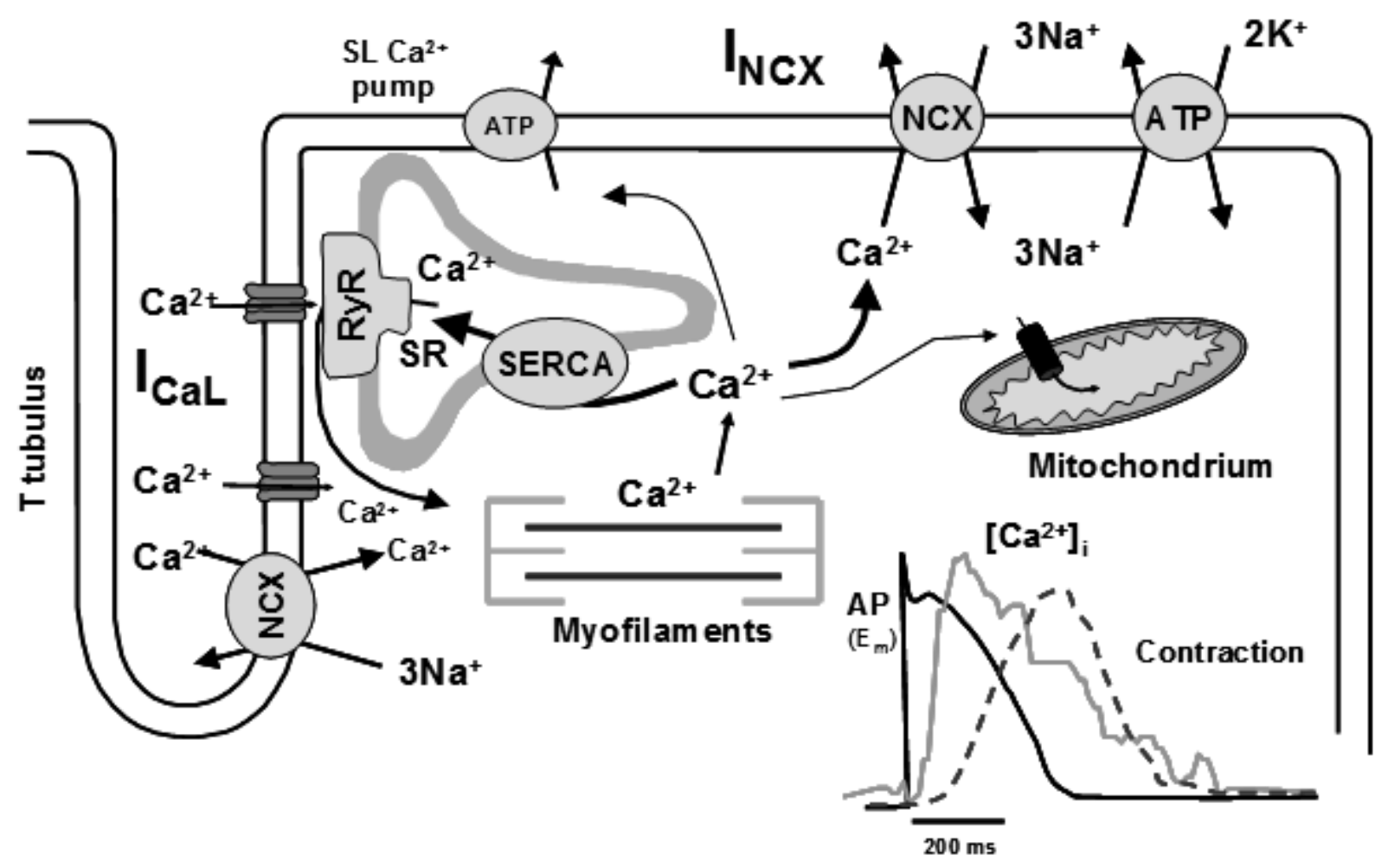

Figure 1 Major $\mathrm{Ca}^{2+}$ transport pathways in ventricular cardiomyocytes. The insert shows the time course of an action potential, $\mathrm{Ca}^{2+}$ transient and contraction measured in a rabbit ventricular myocyte at $37^{\circ} \mathrm{C}$. Abbreviations: SR: sarcoplasmic reticulum; NCX: $\mathrm{Na}^{+} / \mathrm{Ca}^{2+}$ exchanger; ATP: Plasma-membrane $\mathrm{Ca}^{2+}-\mathrm{ATPase}_{\mathrm{N}} \mathrm{Na}^{+} / \mathrm{K}^{+}-$ ATPase; SERCA: SR Ca ${ }^{2+}$-ATPase (Bers DM, 2002)

The combination of $\mathrm{Ca}^{2+}$ influx and release significantly raises the free intracellular $\mathrm{Ca}^{2+}$ concentration $\left(\left[\mathrm{Ca}^{2+}\right]_{\mathrm{i}}\right)$, allowing $\mathrm{Ca}^{2+}$ to bind to the myofilament protein troponin $\mathrm{C}$, which in turn switches the contractile machinery on. Although $\mathrm{Ca}^{2+}$ is the switch that activates the myofilaments, the contraction is graded and depends not only on $\left[\mathrm{Ca}^{2+}\right]_{\mathrm{i}}$ but also on several other factors. The amount of total cytosolic $\left[\mathrm{Ca}^{2+}\right]\left(\left[\mathrm{Ca}^{2+}\right]=\left[\mathrm{Ca}^{2+}\right]_{\mathrm{i}}\right.$ plus bound $\left.\mathrm{Ca}^{2+}\right)$ that must be supplied to and removed from the cytosol during each cardiac beat. For relaxation to occur $\left[\mathrm{Ca}^{2+}\right]_{\mathrm{i}}$ must decline, allowing $\mathrm{Ca}^{2+}$ to dissociate from troponin. This requires $\mathrm{Ca}^{2+}$ transport out of the cytosol by four pathways as follows: 70-90\% of the cytoplasmic $\mathrm{Ca}^{2+}$ is resequestrated into the sarcoplasmic reticulum by the sarcoplasmic reticulum $\mathrm{Ca}^{2+}$ ATPase (SERCA2), 7-30\% is extruded from the cell by the $\mathrm{Na}^{+} / \mathrm{Ca}^{2+}$ exchanger, and only a small amount of $\mathrm{Ca}^{2+}$ is extruded by the slow $\mathrm{Ca}^{2+}$ transport systems, such as the sarcolemmal $\mathrm{Ca}^{2+}$ ATPase (PMCA) and the mitochondrial $\mathrm{Ca}^{2+}$ transport [5]. For steady contractile activity of 
the heart the amount of $\mathrm{Ca}^{2+}$ extruded during relaxation and the amount of $\mathrm{Ca}^{2+}$ entry during each beat must be the same, otherwise the cell would either gain or lose $\mathrm{Ca}^{2+}$. Indeed, complementary measurements of $\mathrm{Ca}^{2+}$ influx and $\mathrm{SR} \mathrm{Ca}^{2+}$ release during a twitch confirm this expectation. This provides a quantitative framework for dynamic $\mathrm{Ca}^{2+}$ fluxes in ventricular myocytes. The ability of the NCX to carry both inward and outward $\mathrm{I}_{\mathrm{NCX}}$ during the same AP and the role of $\mathrm{NCX}$ in $\mathrm{Ca}^{2+}$ extrusion, generation of pacemaker activity and cardiac arrhythmias arrhythmias make crucial the detailed understanding the role of this transporter in $\mathrm{Ca}^{2+}$ handling in normal as well as in pathological conditions.

\subsection{Altered $\mathrm{Ca}^{2+}$ handling in diabetes}

$\mathrm{Ca}^{2+}$ handling is directly or indirectly involved in all major types of cardiac diseases, such as heart failure or cardiac arrhythmias. Diabetes is becoming an increasing health problem worldwide. Although diabetes is associated with a variety of pathological processes, including renal failure and neuropathies, heart disease is the leading cause of mortality among diabetic patients [6]. Although coronary artery disease is considered to be the major complication associated with diabetes, diabetic cardiomyopathy - characterized by decreased contractile performance - is observed even in the absence of notable coronary artery disease [6]. Although the diabetic state affects a number of aspects of normal cardiac myocyte physiology, including alterations in intracellular signaling pathways and energy substrate metabolism, numerous studies have suggested that SR dysfunction, leading to alterations in calcium handling is, indeed, responsible for the decreased contractile performance [7, 8]. This decrease has been demonstrated in vivo and in vitro, in isolated heart and cardiac myocyte preparations. Diabetic cardiomyopathy manifests itself as a decrease in absolute force production, as well as declined rate of force development, indicating that multiple aspects of $\mathrm{Ca}^{2+}$ handling may be involved [9].

Despite the recent advances in this field, our understanding of the initiation and progress of diabetic cardiomyopathy is highly limited. In my thesis I will present the first results of our group in this field, in which study we investigated the possible role of the NCX in the pathological shift in $\mathrm{Ca}^{2+}$ handling in type I diabetes. For this purpose, we used a recently developed NCX inhibitor SEA0400. In the present thesis we also discuss the validation of SEA0400 as an appropriate NCX inhibitor in intact cardiac myocytes. 


\subsection{Optical measurement of the intracellular calcium concentration}

It is known that $\mathrm{Ca}^{2+}$ as a second messenger regulates a wide range of physiological cellular mechanisms. However, it can also trigger pathomechanisms, such as cell injury and death, neurodegeneration, skeletal muscle defects, heart disease and skin disorders. A number of techniques have been developed to quantitate intracellular $\mathrm{Ca}^{2+}$ levels. The majority of these techniques utilize fluorescent $\mathrm{Ca}^{2+}$ indicators. Essentially, these indicators show an increase in magnitude or a shift in their fluorescence spectrum upon binding to $\mathrm{Ca}^{2+}$. There are two major classes of $\mathrm{Ca}^{2+}$ indicator dyes: chemically engineered fluorescent dies and genetically encoded fluorescent proteins. The use of these fluorescent $\mathrm{Ca}^{2+}$ indicators has been a highly successful approach to study the role of $\mathrm{Ca}^{2+}$ in specific intracellular processes and rapidly advanced our understanding of the underlying mechanisms of $\mathrm{Ca}^{2+}$ signaling as well as our appreciation for the ubiquitous role of $\mathrm{Ca}^{2+}$ in cellular activities.

\subsubsection{Chemically engineered fluorescent indicators}

The most widely used fluorescent $\mathrm{Ca}^{2+}$ indicators are chemical probes, because, in general, either the spectral or the intensity change in their fluorescence is relatively large for a given change in $\left[\mathrm{Ca}^{2+}\right]$ compared with other types of $\mathrm{Ca}^{2+}$ indicators. Most of the classical members of this group were produced by Tsien and colleagues $[1,10,11]$. One way to classify these probes into two subgroups is whether they are used as non-ratiometric (single wavelength) or ratiometric indicators. Fluo-3, fluo-4, the calcium green class, and rhod-2 are non-ratiometric, whereas indo-1 and fura-2 are ratiometric dyes. Both subgroups require specific equipment, such as excitation sources, interference filters, and detection techniques, according to their spectral properties and both subclasses have advantages and limitations as well. Fluo-3 and Fluo-4 are probably the most suitable $\mathrm{Ca}^{2+}$ indicators, for their simple use in a wide variety of isolated cell types. Fluo-4 is a brighter, more photostable derivative of Fluo3. Its $\mathrm{Ca}^{2+}$ affinity is slightly lower ( $\mathrm{Kd} 345 \mathrm{nM}$ ) and its absorption maximum is shifted by 12 $\mathrm{nm}$ compared to Fluo-3, making it more suitable for $488 \mathrm{~nm}$ excitation by an argon laser [12]. Because of the lower Kd, fluo- 4 can be used at a lower dye concentrations and thus, it is less phototoxic. Fluo-4 has very low background absorbance and the lower dye concentrations require shorter incubation times [13]. These properties qualify fluo-4 for optimal intracellular free $\mathrm{Ca}^{2+}$ measurement in beating myocytes. 


\subsubsection{Genetically Encoded Calcium Indicators (GECIs)}

Green fluorescent protein (GFP) is a photosensitive protein originally isolated from the jellyfish Aequorea victoria. GFP absorbs the blue luminescent emission of aequorin and gives off green fluorescence in A. victoria [14]. The cloning of GFP gene made possible to fuse its DNA to that of cellular constituents, wich has led to the use of GFP as markers of gene expression and protein localization in living organisms $[15,16]$. The use of GFP and its derivatives have become one of the most popular and exciting new techniques in cell biology. Some groups have successfully constructed GFP based $\mathrm{Ca}^{2+}$ indicators (Fig 2.). Miyawaki and colleagues [17] have expressed GFP-based $\mathrm{Ca}^{2+}$ indicators (called "chameleons") in the cytosol and endoplasmic reticulum of intact HeLa cells. Cameleons consist of four major functional units: two GFP variants emitting fluorescence at different wavelengths, the $\mathrm{Ca}^{2+}$ sensitive protein calmodulin and M13, a 26 amino acid long residue of calmodulin-binding peptide of myosin light-chain kinase. The hybrid protein (calmodulin-M13 complex) bridges the two GFP mutants. When $\mathrm{Ca}^{2+}$ binds to the calmodulin in this complex, the hybrid protein changes its conformation, which results in the decrease in the distance between the two GFP mutants and an increase in fluorescence resonance energy transfer (FRET). This first version of Cameleon has been progressively modified in several ways including a decrease in $\mathrm{pH}$ sensitivity of the photon acceptor in the yellow cameleons [18, 19].

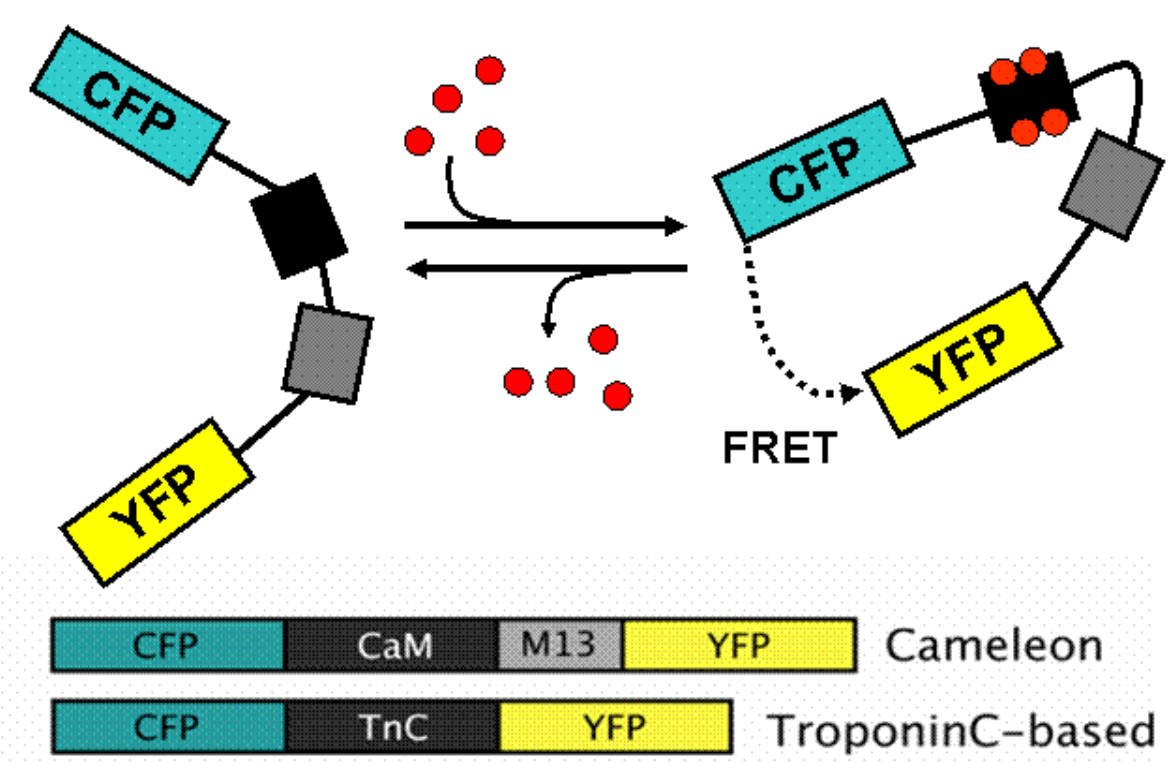

Figure 2. Working schema of GECIs. GECIs consist of two GFP variants (CFP and YFP) of which spectra allow FRET between them when all other required conditions are met and a $\mathrm{Ca}^{2+}$-sensitive module: a hybrid of a $\mathrm{Ca}^{2+}$ binding domain of calmodulin and the M13 myosin light chain kinase peptide or troponin C in case of Cameleon and Troponeon, respectively. Binding of $\mathrm{Ca}^{2+}$ to the $\mathrm{Ca}^{2+}$-sensitive module results in conformation changes which in turn facilitates FRET between CFP and YFP. Lower paner: Schematic map of the Cameleon and Troponeon GECIs. 
Roger Tsien and coworkers demonstrated two improved combinations of donor and acceptor GFP mutant pairs, blue fluorescent protein (BFP)/GFP and cyan fluorescent protein (CFP)/yellow fluorescent protein (YFP). Their excitation wavelength and emission ratio are 380-510/445 and 440-535/480 $\mathrm{nm}$, respectively [19].

Heim and Griesbeck [20] developed novel types of calcium probes called troponeons. Troponeons are based on troponin $\mathrm{C}$ variants from skeletal and cardiac muscle, and mutants of the green fluorescent protein (CFP and citrine). Troponeon has ratio changes up to $140 \%$, Kd values ranging from $470 \mathrm{nM}$ to $29 \mu \mathrm{M}$, and improved subcellular targeting properties. The authors clearly demonstrate their usefulness of troponeons for dynamic $\mathrm{Ca}^{2+}$ imaging within live cells.

\subsubsection{Benefits and pitfalls: chemically versus genetically encoded $\mathrm{Ca}^{2+}$ indicators}

A major advantage of chemical indicators over genetically encoded fluorescent proteins is the broad range of dyes of various $\mathrm{Ca}^{2+}$ affinities that are commercially available for the user and the relative easy of use of the these dyes for experiments. Chemical $\mathrm{Ca}^{2+}$ indicators are easy to introduce into cells, cell-loading protocols for chemical $\mathrm{Ca}^{2+}$ indicators have been well-established [21]. A major disadvantage is that the intracellular localization of these $\mathrm{Ca}^{2+}$ indicators cannot be easily controlled or specifically targeted to a particular organelle. In addition, chemical indicators tend to compartmentalize and are eventually extruded from the cell during long recording experiments [22]. A relatively simple, yet successful strategy to combat the compartmentalization problem has been to generate indicators with a large dextran tag [23]. This strategy permits extended periods of $\mathrm{Ca}^{2+}$ level recordings up to days at a time. However, a limitation of dextran tagged dyes is that they are more difficult to load and generally need to be directly injected into cells.

GECIs are not expressed endogenously, their genetic material needs to be introduced experimentally. GECIs can be stably expressed by genetic modifications of the cell line or the animal that is being studied, or they can be transiently expressed by one of the physicochemical or virus-based gene transfer techniques. Therefore, the use of GECIs relies on sophisticated molecular biological infrastructure in most of the cases. On the other hand, among the several others, the most important advantage GECIs offer is the possibility to target specific cellular compartments or specific subcellular loci by creating fusion proteins of a GECI and an endogenously expressed protein or by using special targeting sequences, the so-called signal peptides [13]. The latter two techniques may allow us to study $\mathrm{Ca}^{2+}$ fluctuations at specific subcellular locations. 


\subsubsection{Gene transfer techniques: advantages and limitations}

Viruses had millions of years to evolve the ability to efficiently infect their host cells. During infection, the viruses deliver their own genetic material into the host cell, which ability can be employed by utilizing viruses as vectors for delivering exogenous genes to a broad range of cell types. Virus-mediated gene transfer methods have become powerful and widely used experimental tools in biological research. In the case of adult cardiomyocytes the efficiency of most of the gene transfer techniques that work well in other systems is highly limited because cardiac cells do not divide, have a relatively short lifetime in culture and are highly sensitive to toxic effects. Gene transfer methods in general and in cardiovascular research as well can be divided into two groups: physicochemical (or non-viral) and viral vector-based systems. Non-viral methods involve cationic liposome/plasmid DNA complexes, incubation with naked DNA, and calcium phosphate precipitation [24, 25]. Non-viral techniques suffer from severe limitations such as very low transfection efficiency especially in in vivo applications, cytotoxicity and short-term expression of transduced genes due to intracellular degradation of foreign DNA. The above limitations urged the application of more efficient virus vector-based approaches for gene delivery to the cardiovascular system. The following viral systems have been applied in molecular cardiology: adenoviruses (AdVs), adeno-associated viruses (AAVs), retroviruses (RV) like lentivirus (HIV-1) and herpes simplex virus (HSV-1)-derived vectors [24, 25]. Currently, AdVs and AAVs are the most frequently used tools for delivering genes into the cells of the cardiovascular system, both in vivo and in vitro $[26,27]$. While $\mathrm{AdV}$-based vectors allow relatively highly efficient delivery of transgenes to cardiac cells, this system provides only transient expression of transferred genes since the virus does not integrate into the host genome [28]. The application of AdVs have further limitations including strong immune responses by the host organism, limited payload size and during propagation may have moderately difficult quality control. An additional problem with AdV systems is related to the infection efficiency. The coxsackie adenovirus receptor (CAR) is a key determinant for the attachment and cellular uptake of AdVs [29]. However, CAR expression is maximal in neonates and is reduced rapidly after birth in several organs such as heart, muscle and brain resulting in lower penetration rate of adenovirus vectors [30]. Recombinant AAV vectors are able to effectively transduce foreign genes to a variety of cell types including both dividing and post-mitotic cells in both in vitro and in vivo experimental systems [31]. The AAV-based systems have a number of favourable attributes, such as minimal immunogenicity, lack of parental agent pathogenicity and vectorrelated cytotoxicity, and the capacity for stable long-term transgene expression. The main 
disadvantages of AVV vector-based approaches include the difficulty of producing high-titer virus stocks of consistent purity and bioactivity, and the limited packaging capacity of a maximum $4.8 \mathrm{~kb}$ insert-size [32]. Lentivirus-based gene transfer has been reported in a wide variety of cell types, including cardiomyocytes [33]. Current lentiviral vectors are capable of transducing mitotically quiescent cells, particularly within the cardiovascular system. The strengths of this system include the ability of long-term stable transgene expression, an increased packaging capacity compared with AAV, and the other commonly used integrating vector [34]. The disadvantages of lentivirus-based gene delivery systems are the relative low level of transgene expression and the limited transgene carrying capacity of the virus.

Pseudorabies virus (PRV), a causative agent of Aujeszky's disease of swine, is an alphaherpesvirus belonging to family of Herpesviridae. Several previous reports have been successful in construction of PRVs for delivering foreign genes to neurons [35]. PRV is an especially important tool for labelling neuronal circuits [36], which was combined with delivery of activity markers to labelled neurons [37]. Application of PRV-based gene transfer vectors in the cardiovascular research field has not yet been reported.

\section{MATERIALS AND METHODS}

\subsection{Isolation of cardiomyocytes}

All experiments were conducted in compliance with the Guide for the Care and Use of Laboratory Animals. The protocols were approved by the review board of the Committee on Animal Research of the University of Szeged, Szeged, Hungary.

New Zealand rabbits weighing 1.5 - $2.0 \mathrm{~kg}$ were used. Each animal was anaesthetized by intravenous infusion of $30 \mathrm{mg} \mathrm{kg}^{-1}$ pentobarbital and sacrificed by cervical dislocation after an intravenous injection of $400 \mathrm{IU} \mathrm{kg}^{-1}$ heparin. Rabbit ventricular myocytes were produced by enzymatically dissociation. The chest was opened, the heart quickly removed and placed into cold $\left(4^{\circ} \mathrm{C}\right)$ Krebs-Henseleit $(\mathrm{KH})$ solution with the following composition (mM): $\mathrm{NaCl} 135, \mathrm{KCl} 4.7, \mathrm{KH} 2 \mathrm{PO} 4$ 1.2, $\mathrm{MgSO}_{4}$ 1.2, HEPES 10, $\mathrm{NaHCO}_{3} 4.4$, Glucose 10, $\mathrm{CaCl}_{2}$ 1.8. The $\mathrm{pH}$ of this solution was 7.4 when saturated with a mixture of $95 \% \mathrm{O}_{2}$ and $5 \%$ $\mathrm{CO}_{2}$. The heart was then mounted on a modified Langendorff column (Fig. 3) and perfused with oxygenated perfusate of the same composition warmed to $37^{\circ} \mathrm{C}$. Perfusion was continued with $\mathrm{Ca}^{2+}$-free Krebs-Henseleit solution for further $5 \mathrm{~min}$, then the perfusate was completed with collagenase $\left(0.05 \%\right.$, type I), hyaluronidase $(0.05 \%)$ and $\mathrm{CaCl}_{2}(200 \mu \mathrm{M})$ and the heart was perfused for additional $15 \mathrm{~min}$. Finally the left ventricular myocardium was minced and 
gently agitated. The cells freshly released from the tissue were stored in storage solution at room temperature before use.

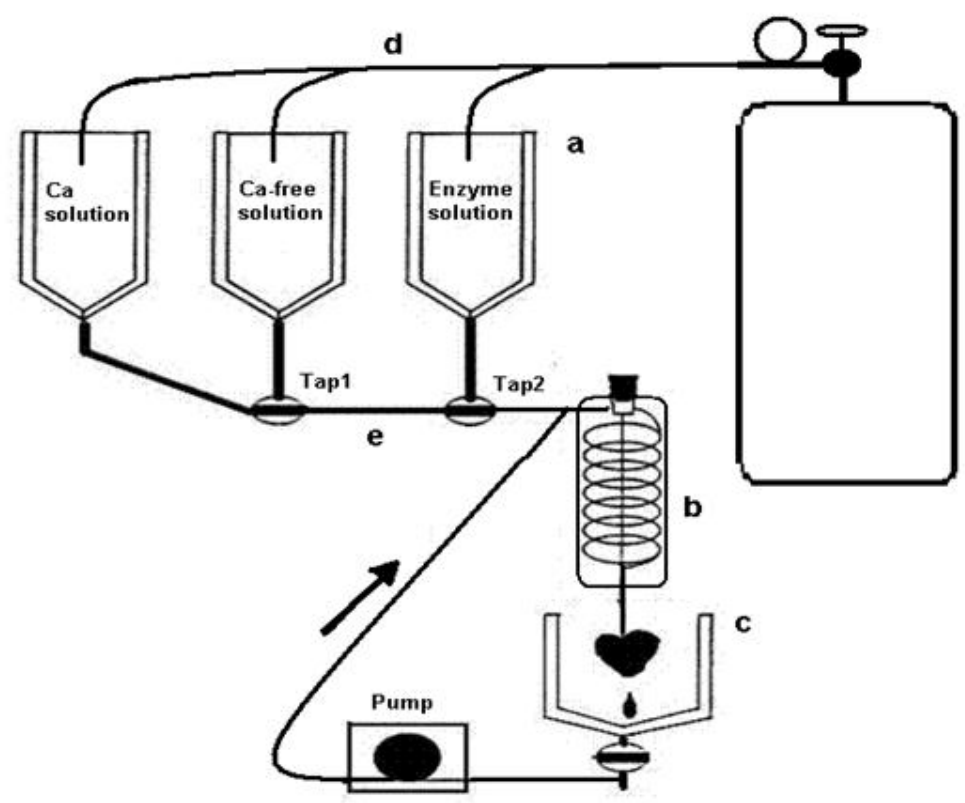

Figure 3. Schematic illustration of the Langendorff apparatus used to isolate single cardiac myocytes at $37^{\circ} \mathrm{C}$ from beating heart. The apparatus consists of: a) Temperature controlled $\left(37^{\circ} \mathrm{C}\right)$ water-jacketed solution reservoirs $(300 \mathrm{ml})$. b) Glass-coil heat exchanger with heart cannula and bubble trap; c) Water-jacketed reservoir to warm the heart and collect recirculating solution; d) Gas bubblers e) Three-way taps for rapid switching between solutions.

The storage solution contained in $\mathrm{mM}: \mathrm{KOH} 89, \mathrm{~L}$-glutamic acid 70, taurine $15, \mathrm{KCl} 30$, $\mathrm{KH}_{2} \mathrm{PO}_{4} 10$, HEPES $10, \mathrm{MgCl}_{2}$ 0.5, glucose 11 , EGTA 0.5 , and $\mathrm{pH}$ was set to 7.3 with $\mathrm{KOH}$. The cells were rod shaped and showed clear striation when the external calcium was restored. Using the apparatus shown in Figure 3, rabbit hearts were perfused retrogradely through the aorta, and thus through the coronary arteries, which supply the muscle of the ventricles. The same apparatus, with modified solution flow-rates and cannulae, was used for canine left ventricle isolations.

Canine ventricular myocytes were enzymatically dissociated as follows. A portion of the left ventricular wall containing an arterial branch large enough to cannulate was perfused in a modified Langendorff apparatus (Fig. 3) with solutions in the following sequence: 1) normal Tyrode's solution $(10 \mathrm{~min}), 2) \mathrm{Ca}^{2+}$-free Tyrode solution $(10 \mathrm{~min})$, and 3) $\mathrm{Ca}^{2+}$-free Tyrode solution containing collagenase (type $\mathrm{I}, 0.66 \mathrm{mg} / \mathrm{ml}$ ) and bovine serum albumin (fraction $\mathrm{V}$, fatty acid free, $2 \mathrm{mg} / \mathrm{ml}$ ) (15 min). Protease (type XIV, $0.12 \mathrm{mg} / \mathrm{ml}$ ) was added to the final perfusate while and another 15 - 30 min of digestion was allowed. Cells were stored in Kraft Brühe (KB) solution. The composition of solutions were (in $\mathrm{mM}$ ): a) normal Tyrode's 
solution - $\mathrm{NaCl}$ 135, $\mathrm{KCl}$ 4.7, $\mathrm{KH} 2 \mathrm{PO}_{4}$ 1.2, $\mathrm{MgSO}_{4}$ 1.2, HEPES 10, $\mathrm{NaHCO}_{3} 4.4$, glucose 10, and $\mathrm{CaCl}_{2} 1.0$ (pH 7.2 adjusted with $\mathrm{NaOH}$ ); b) $\mathrm{Ca}^{2+}$-free Tyrode solution $-\mathrm{NaCl} 135, \mathrm{KCl}$ 4.7, $\mathrm{KH}_{2} \mathrm{PO}_{4}$ 1.2, $\mathrm{MgSO}_{4}$ 1.2, HEPES 10, $\mathrm{NaHCO}_{3}$ 4.4, Glucose 10, and taurine 20 (pH 7.2 adjusted with $\mathrm{NaOH}$ ); c) $\mathrm{KB}$ solution - $\mathrm{KOH} \mathrm{90,} \mathrm{L-glutamic} \mathrm{acid} \mathrm{70,} \mathrm{taurine} \mathrm{15,} \mathrm{KCl} 30$, $\mathrm{KH}_{2} \mathrm{PO}_{4} 10, \mathrm{MgCl}_{2}$ 0.5, HEPES 10, glucose 11, and EGTA 0.5 ( $\mathrm{pH} 7.3$ adjusted with $\mathrm{KOH}$ ). All chemicals used in this method were purchased from Sigma Chemical Co.

\subsection{Induction of experimental type 1 diabetes}

This protocol for induction of diabetes was based on established procedures described earlier Lengyel et al. [38]. Briefly, male New Zealand white rabbits $(\mathrm{n}=19)$, weighing 1.5$2.0 \mathrm{~kg}$, were used in this experiment. Diabetes mellitus was induced in 10 rabbits by infusion of a single intravenous dose of alloxan (145 mg kg-1) (alloxan monohydrate, Sigma, St Louis, MO, USA) into the ear vein under pentobarbital anaesthesia (26-30 $\mathrm{mg} \mathrm{kg}^{-1}$ i.v., Nembutal; CEVA, Paris, France), after fasting overnight. Blood glucose was measured twice weekly from blood samples obtained from the ear vein. Untreated animals were used as controls. Body weight and plasma glucose levels were determined in each animal at the beginning as well as at the end of the experiment (just prior to the electrophysiological analysis). We opted for this 3-week model based on previous studies performed in streptozotocine-induced rat/mouse models, where the electrophysiological remodelling effects were investigated after 2-4 weeks of diabetic period [39, 40] After 3 weeks diabetic rabbits were used for myocyte isolation and intracellular calcium measurements.

\subsection{Optical measurements}

\section{Simultaneous recording of caffeine induced and steady-state $\left[\mathrm{Ca}^{2+}\right]_{\mathrm{i}}$ transients and cell shortening in field stimulated cardiomyocytes}

Freshly isolated myocytes were loaded by incubation for $20 \mathrm{~min}$ with the acetoxymethyl ester (AM) form of a single wavelength calcium-sensitive fluorescent dye (Fluo-4, Molecular Probes Inc. $2 \mu \mathrm{M}$ from a stock of $1 \mathrm{mM}$ in DMSO $+20 \%$ pluronic acid) at room temperature. Loaded myocytes were mounted in a low volume imaging chamber (RC47FSLP, Warner Instruments,). and placed on the stage of an inverted fluorescent microscope (IX71, Olympus, Japan) and the cells were superfused with normal Tyrode solution at $37^{\circ} \mathrm{C}(1 \mathrm{ml} / \mathrm{min})$.

Caffeine was originally isolated from coffee such as white crystalline xanthine alkaloid which is a psychoactive stimulant in the central nervous system. Among its numerous effects 
it also induces $\mathrm{Ca}^{2+}$ transient in heart muscle cell through activating RyRs. $\left[\mathrm{Ca}^{2+}\right]_{\mathrm{i}}$ transients were induced by applying $5 \mathrm{~mL}$ caffeine $(10 \mathrm{mM})$-containing Tyrode solution for $6 \mathrm{~s}$ at a flow rate of $50 \mathrm{~mL} / \mathrm{min}$ directly onto the cell surface from a micropipette. These micropipettes, having typical tip diameter of $100 \mu \mathrm{m}$, were positioned by a manipulator to $\sim 100 \mu \mathrm{m}$ distance from the cell. The control caffeine flush was repeated after 2 min, then $1 \mu \mathrm{M}$ SEA0400 was superfused for $5 \mathrm{~min}$, and the caffeine flushes were applied again. The $2 \mathrm{~min}$ period of time spent between the consecutive flushes was sufficient for the cells to recover from the caffeine transient, i.e. the two subsequent challenges yielded close to identical responses, otherwise data were discarded. The two control and two SEA0400 curves were corrected against dark current, non-specific background, and bleaching artefact, averaged, and normalized so as to have identical amplitudes. When studying the effect of $\mathrm{Ni}^{2+}$, the cells were exposed to $10 \mathrm{mM}$ $\mathrm{NiCl}_{2}$-containing Tyrode for $15 \mathrm{~s}$ prior to the beginning of the caffeine pulse and $\mathrm{Ni}^{2+}$ concentrations were maintained throughout the caffeine exposure.

For steady-state $\left[\mathrm{Ca}^{2+}\right]_{\mathrm{i}}$ measurements myocytes were stimulated at a constant frequency of $1 \mathrm{~Hz}$ through a pair of platinum electrodes by an electronic stimulator (Experimetria Ltd, Hungary). The dye was excited at $480 \mathrm{~nm}$, fluorescence emission was recorded at $535 \mathrm{~nm}$ (Chroma, USA). Optical signals were recorded by a photon counting photomultiplier module (H7828, Hamamatsu, Japan) and sampled at $1 \mathrm{kHz}$. Measurements were performed and data were analyzed using the Isosys software (Experimetria, Hungary). Cell shortening from both ends was determined by a video edge detection system (VED-105, Crescent Electronics, Sandy, Utah, USA) (Fig 4.). All data are expressed as mean \pm SEM.

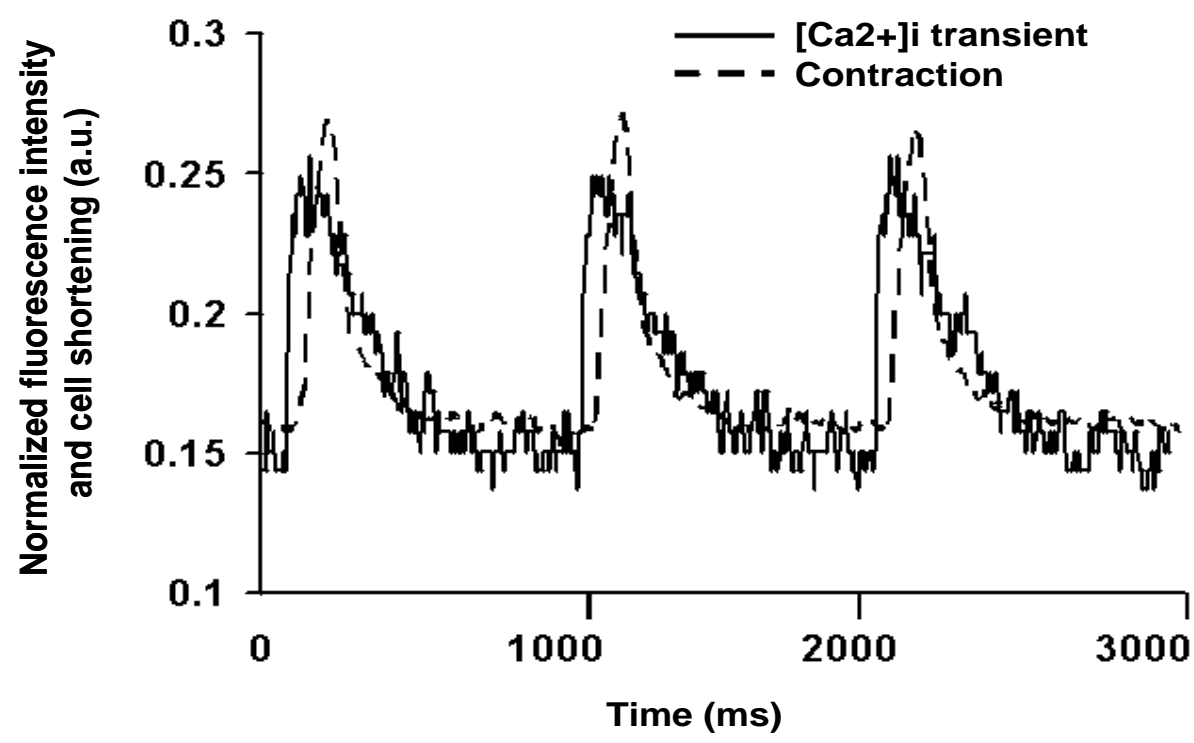

Figure 4. Representative recordings of the intracellular $\mathrm{Ca}^{2+}$ transient and cell shortening. These parameters are detected in parallel by a photon counting system and a video edge detector. 


\subsection{Methods for experiments using GECIs}

\section{Reporter genes}

A troponeon variant (Tn-15), [20] was used as a GECI. The troponeon gene was placed under the control of the major immediate early promoter of human cytomegalovirus (pCMV), which provided a high level of gene expression. The marker gene expression cassette also contained simian virus 40 (SV40)-derived sequences including polyadenylation signal and transcription termination sequences. In addition, a lacZ gene equipped with the above regulatory sequences was also used as a reporter gene for the identification of mutant viruses.

\section{Construction of targeting vectors}

In our molecular cloning system, we use so-called targeting plasmids that combine with the parental virus genome by homologous recombination. A typical targeting plasmid contains a gene expression cassette of the gene that is to be introduced into the virus genome and subcloned viral DNA sequences flanking the expression cassette, which serve as homologous DNA regions for the recombination. The homologous recombination that occurs between the targeting plasmid and the virus genome results in a modified virus genome that carries the expression cassette. To adapt for applicability as virus vector we deleted the two ribonucleotide reductase (rr) and the early protein (ep0) genes from the virus genome by homolog recombination. The rr1 and rr2 genes are in charge for production of raw material of viral DNA. The recombinant virus is not able to productively infect postmitotic cells without rr genes, while ep0 gene is responsible for virus reactivation from latency. Troponeon gene (csTnC-L15) was inserted to antisense internal and external repeat (IR, TR) region in two copies. The DNA sequences used for mutagenesis and as insertion sites for reporter genes are listed in Fig. 5. 


\section{Pseudorabies virus (PRV)}

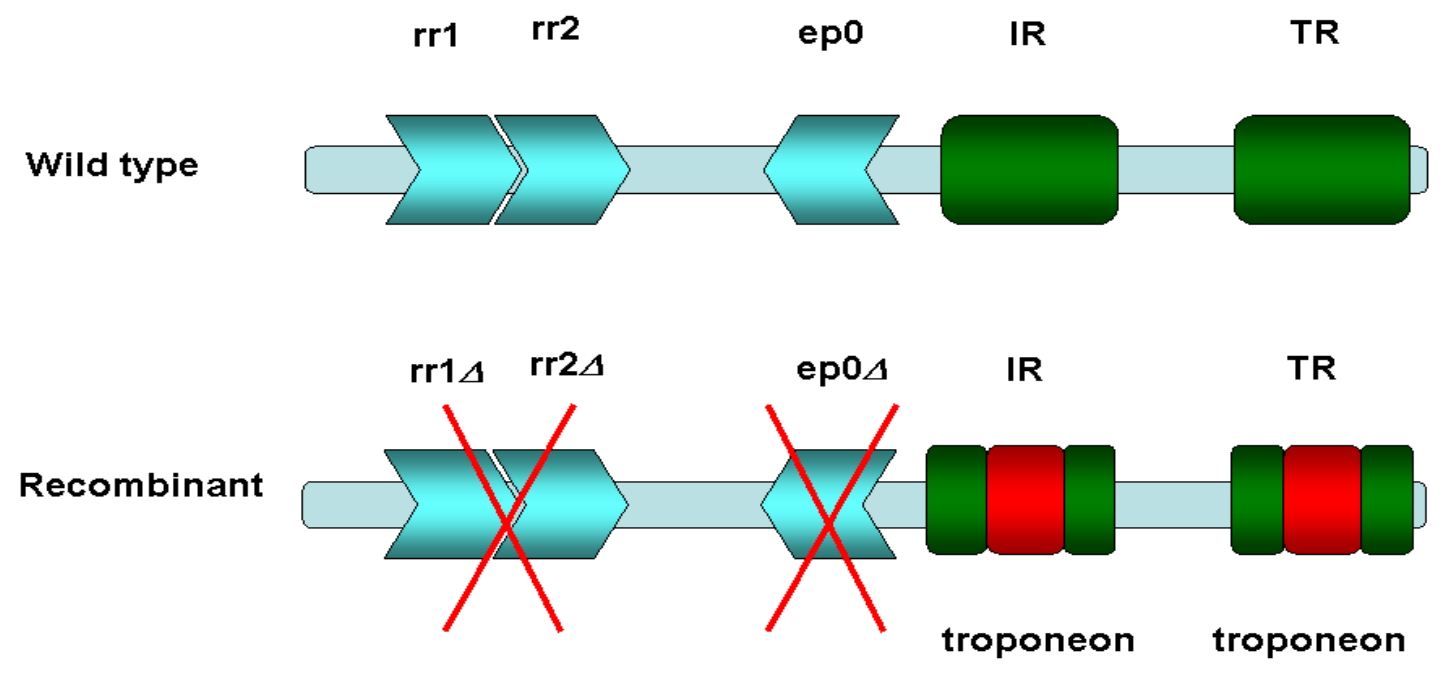

Figure 5. This panel shows the schematic illustration of wild type and recombinant herpes virus genom. Abbreviations: rr1: ribonucleotide reductase 1; rr2: ribonucleotide reductase 2; ep0: early protein 0; IR: inner repeat; TR: external repeat

\section{Culture and infection of myocytes}

The protocol for cell isolation was based on established procedures described earlier in chapter "4.1 Isolation of cardiomyocytes".

The entire culture procedure was performed in a class II flow hood. The freshly isolated myocytes were centrifuged five times for $1 \mathrm{~min}$ at $50 \mathrm{~g}$ in sterile $10 \% \mathrm{PBS}$. The supernatant was replaced first by $500 \mu \mathrm{M}$ then by $1 \mathrm{mM} \mathrm{Ca}^{2+}$ containing PBS solution. The mild centrifugation steps removed the majority of bacterial cells, most non-myocytes and nonfunctioning myocytes. Precipitated cells were resuspended in culture medium and plated on laminin coated $(1 \mu \mathrm{g} / \mathrm{cm} 2)$ sterile cover glass at densities of up to $10^{3}$ rod-shaped cells $\mathrm{cm}^{-2}$. Cells were left 4 hours to attach to the plate and after this time period non-attached cells were removed. Following the first medium change, subsequent medium changes were carried out every day. Culture medium consisted of serum-free medium 199 (M199) supplemented with $25 \mathrm{mM} \mathrm{NaHCO} 3,5 \mathrm{mM}$ ceratine, $2 \mathrm{mM}$ L-carnitine, $5 \mathrm{mM}$ taurine, 100 units $/ \mathrm{ml}$ insulin (CCTI supplemented medium) and $50 \mu \mathrm{g} / \mathrm{ml}$ gentamycin. All chemicals used in this procedure were purchased from Sigma. Cells were maintained at $37^{\circ} \mathrm{C}$ under sterile conditions in an incubator ventilated with $5 \% \mathrm{CO}_{2}$ and $95 \%$ air. After 4 hours, plate attached cells were infected. Freshly isolated canine cardiomyocytes were first washed with PBS, followed by low-speed centrifugation and resuspension in culture medium. Subsequently, after 4-hour 
incubation at $37{ }^{\circ} \mathrm{C}$ in a $\mathrm{CO}_{2}$ incubator, cells were infected with various titers of recombinant viruses for 12 hours then washed and the culture medium was changed. Infected cells were used for analysis at various time points.

\section{Evaluation of infection efficacy and morphological changes in cultured cells}

Cell shape and morphology are closely linked with some aspects of cell function such as excitation-contraction coupling. Therefore, monitoring these properties may give indications of physiological changes that are occurring. Morphological changes of cells were observed by light microscopy on a daily basis parallel with physiological measurements. Troponeonpositive cells were examined by fluorescence microscopy from one to three days following isolation at standard titer of viruses. Infection efficacy was determined separately for infected cells by manual cell counting using a fluorescent microscope (Olympus IX-71).

\section{Evaluation of the electrophysiological state of the cells by $\mathbf{I}_{t_{0}}$ analysis}

$\mathrm{I}_{\text {to }}$ currents were measured using the whole-cell configuration of the patch-clamp technique. Measurements were performed daily starting with day 0 , when only freshly isolated non-infected myocytes were investigated. In the following days control and infected cells were studied separately by placing cover glasses with the attached cells in the recording chamber mounted on the stage of an inverted microscope equipped with epifluorescence assembly (Olympus IX50, Tokyo, Japan). Only rod-shaped cells with clear cross striations and relatively strong GFP signal were used. HEPES-buffered Tyrode's solution containing (in $\mathrm{mM}$ ): $\mathrm{NaCl} 144, \mathrm{NaH}_{2} \mathrm{PO}_{4} 0.33, \mathrm{KCl} 4.0, \mathrm{CaCl}_{2} 1.8, \mathrm{MgCl}_{2} 0.53$, glucose 5.5 and HEPES 5.0 at $\mathrm{pH}$ of 7.4 (by $\mathrm{NaOH})$ served as normal superfusate. Cell capacitance $(199.3 \pm 13.7 \mathrm{pF}, \mathrm{n}=69)$ was determined by applying a $10 \mathrm{mV}$ hyperpolarizing pulse from a holding potential of -10 $\mathrm{mV}$. Cell capacity was calculated as the integral of the capacitive transient divided by the amplitude of the voltage step. Patch-clamp micropipettes were fabricated from borosilicate glass capillaries (Clark, Reading, UK) using a P-97 Flaming/Brown micropipette puller (Sutter Co, Novato, CA, USA). These electrodes had resistances between 1.5 and $2.5 \mathrm{Mohms}$ when filled with pipette solution containing (in $\mathrm{mM}$ ): $\mathrm{K}$-aspartate $100, \mathrm{KCl} \mathrm{45,} \mathrm{K}_{2} \mathrm{ATP} 3$, $\mathrm{MgCl}_{2}$ 1, EGTA 10 and HEPES 5. The $\mathrm{pH}$ of this solution was adjusted to 7.2 by $\mathrm{KOH}$. Membrane currents were recorded with Axopatch-200B patch-clamp amplifiers (Axon Instruments, Foster City, CA, USA). After establishing a high (1-10 GOhm) resistance seal by gentle suction, the cell membrane beneath the tip of the electrode was disrupted by suction or by application of $1.5 \mathrm{~V}$ electrical pulses for $1-5 \mathrm{~ms}$. The series resistance was typically $4-8$ 
MOhm before compensation (50 - 80\%, depending on the voltage protocols). Experiments where the series resistance was high, or substantially increased during measurement, were discarded. Membrane currents were digitized using a $333 \mathrm{kHz}$ analogue-to-digital converter (Digidata 1200, Axon Instruments) under software control. Analyses were performed using pClamp 8.0 (Axon Instruments) software after low-pass filtering at $1 \mathrm{kHz}$. All patch-clamp data were collected at $37^{\circ} \mathrm{C}$.

\section{Evaluation of cell function by monitoring $\left[\mathrm{Ca}^{2+}\right]_{\mathrm{i}}$ transient and cell shortening.in field stimulated primary cell culture}

24-72 hours following culturing or viral infection cardiomyocytes were loaded with the acetoxymethyl ester (AM) from a single wavelength calcium-sensitive fluorescent dye (Fluo4, Molecular Probes Inc. $2 \mu \mathrm{M}$ ) at room temperature. The technique for calcium transient detection was based on established procedures described earlier in chapter "Recording of $\left[\mathrm{Ca}^{2+}\right]_{\mathrm{i}}$ transients and cell shortening in field stimulated myocytes"

\section{Evaluation of the functionality of the transduced GECI}

To test full functionality of the transferred troponeon gene, calcium transients were monitored using a dual channel photon counting system in cardiomyocytes expressing troponeon. The troponeon was excited at $480 \mathrm{~nm}$, fluorescence emission was recorded at 535 and $485 \mathrm{~nm}$ (Chroma, USA). The cells were superfused with normal Tyrode solution at $37^{\circ} \mathrm{C}$ $(1 \mathrm{ml} / \mathrm{min})$. Myocytes were stimulated at a constant frequency of $1 \mathrm{~Hz}$. The cells were superfused with normal Tyrode solution at $37^{\circ} \mathrm{C}(1 \mathrm{ml} / \mathrm{min})$. Myocytes were stimulated at a constant frequency of $1 \mathrm{~Hz}$ through a pair of platinum electrodes by an electronic stimulator. Optical signals were recorded by two photon counting photomultiplier module (H7828, Hamamatsu, Japan), and sampled at $1 \mathrm{kHz}$. Changes in $\left[\mathrm{Ca}^{2+}\right]_{\mathrm{i}}$ levels were characterized by the ratio of emitted fluorescence intensities obtained at 485 and $535 \mathrm{~nm}$ wavelengths, ( $\mathrm{F}_{\mathrm{CITRINE}} 535$ / $\mathrm{F}_{\mathrm{CFP}} 485$ ) following correction for non-specific background fluorescence. 


\subsection{Chemicals}

All chemicals were purchased from Sigma-Aldrich (St. Louis, MO, USA), except SEA0400 and Fluo-4 AM. Calium sensitive fluorescent dye Fluo-4 AM was purchased from Molecular Probes Inc. (Eugene, Oregon, USA). SEA0400 was synthesized based on the description of Aibe et al. (2000) at the Department of Pharmaceutical Chemistry (University of Szeged, Hungary). SEA0400 was dissolved in dimethyl sulfoxide (DMSO) and its final concentrations were 0.3 or $1 \mu \mathrm{M}$ when diluted in Tyrode solution.

\subsection{Data analysis}

The fluorescent recordings were corrected for background fluorescence and the change of fluorescence intensity by bleaching in the case of troponeon expressing cells.

All results and optical measurements were compared using Student's t-tests for paired and unpaired data and expressed as mean \pm SEM values. Statistical significance of differences obtained between control and virus infected preparations was evaluated with Student's t-test for paired or unpaired data, as relevant. Differences were considered significant when $\mathrm{p}<0.05$. 


\section{RESULTS}

\subsection{Characterization of the NCX inhibiting effect of SEA0400 in canine cardiomyocytes}

Previous studies demonstrated that SEA0400 may have different efficacy in inhibiting the NCX, depending on the intracellular ionic composition [41]. These results may question the use of SEA0400 as a research tool in the $\mathrm{Ca}^{2+}$ handling research. Therefore in our first experiments we characterized the NCX inhibiting effect of SEA0400 in a setting, where long lasting, high $\left[\mathrm{Ca}^{2+}\right]_{\mathrm{i}}$ level was achieved by the application of $10 \mathrm{mM}$ caffeine. Under these conditions $\mathrm{Ca}^{2+}$ dependent NCX inhibiting effect of SEA0400 can be assumed to be maximal, consequently, in the experiments on the diabetic rabbit heart cells the actual degree of NCX block was presumably at least as high as in the caffeine experiments. Since the relaxation kinetics of a $\left[\mathrm{Ca}^{2+}\right]_{i}$ transient reflects the kinetic properties of $\mathrm{Ca}^{2+}$ elimination from the cytosol, NCX inhibition should be reflected in an elongation of the decay of $\left[\mathrm{Ca}^{2+}\right]_{\mathrm{i}}$ transients. Therefore, the effect of $1 \mu \mathrm{M}$ SEA0400 was studied on $\left[\mathrm{Ca}^{2+}\right]_{\mathrm{i}}$ transients evoked by superfusion with $10 \mathrm{mM}$ caffeine for $6 \mathrm{~s}$.
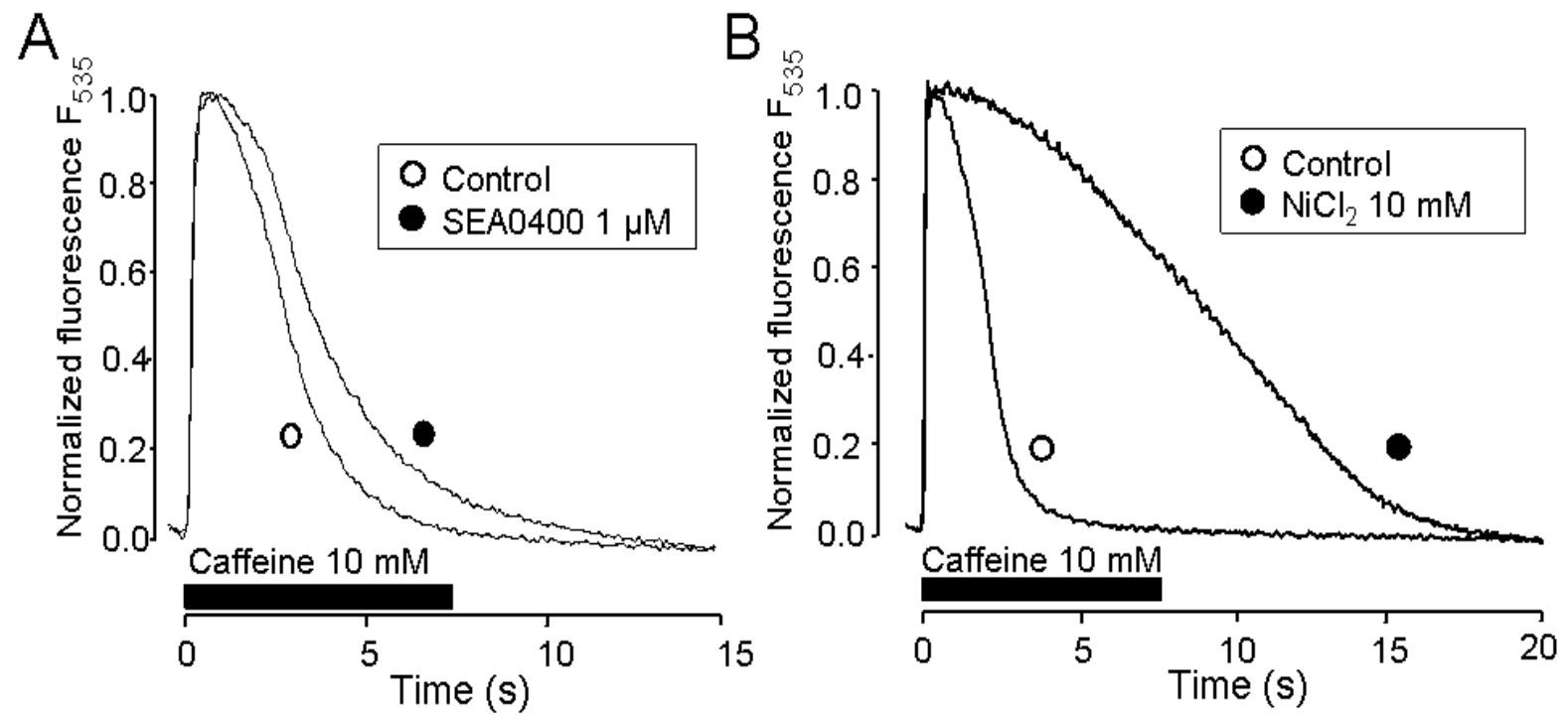

Figure 6 Representative superimposed records showing the effect of $1 \mathrm{mM} \mathrm{SEA0400} \mathrm{(A)} \mathrm{and} 10 \mathrm{mM} \mathrm{NiCl}_{2}(\mathrm{~B})$ on the time course of the $\left[\mathrm{Ca}^{2+}\right]_{i}$ transients elicited by superfusion of $10 \mathrm{mM}$ caffeine for $6 \mathrm{~s}$. Before the application of caffeine, the myocytes were continuously paced at a frequency of $1 \mathrm{~Hz}$.

In order to compare the time course of decay, the transients were normalized to identical amplitudes and superimposed (Fig. 6).The decay time constant, determined using monoexponential fit, was significantly increased by $1 \mu \mathrm{M}$ SEA0400 from $1.03 \pm 0.05$ to $1.32 \pm 0.06 \mathrm{~s}$ $(\mathrm{P}<0.05, \mathrm{n}=10)$, whereas the respective time-matched control values (i.e. when SEA0400 was omitted from the solution) were $0.96 \pm 0.05$ and $0.95 \pm 0.04 \mathrm{~s}(\mathrm{n}=8)$. These results directly 
prove that under the given conditions, SEA0400 is capable to partially inhibit NCX. The NCX-blocking potency of SEA0400 can be qualitatively evaluated by comparing with that of $10 \mathrm{mM} \mathrm{NiCl}_{2}$, which is known to fully block the exchanger. As in the presence of $\mathrm{NiCl}_{2}$ the decaying limb could not be fitted exponentially, the time of half-relaxation was determined: it was increased by $\mathrm{NiCl}_{2}$ from $1.3 \pm 0.1$ to $10.1 \pm 1.3 \mathrm{~s}(\mathrm{P}<0.05, \mathrm{n}=4)$. Although the effect of $1 \mu \mathrm{M}$ SEA0400 on the rate of decay of the caffeine-induced $\left[\mathrm{Ca}^{2+}\right]_{\mathrm{i}}$ transient was only a fraction of that observed with $10 \mathrm{mM} \mathrm{NiCl}_{2}$, it was clearly detectable. However, these results suggest that the NCX-blocking effect of SEA0400 may be relatively moderate when $\left[\mathrm{Ca}^{2+}\right]_{\mathrm{i}}$ is elevated.

\subsection{Evaluation of intracellular $\mathrm{Ca}^{2+}$ changes during type 1 diabetes in rabbit myocytes}

\subsubsection{Changes of intracellular $\mathrm{Ca}^{2+}$ transients and cell shortening in the alloxan-induced diabetic rabbit myocytes}

Since the mechanisms that underlie diastolic dysfunction observed in diabetes are not well understood, we tested the hypothesis that diastolic dysfunction is associated with impaired myocardial $\mathrm{Ca}^{2+}$ handling, $\mathrm{NCX}$ and/or SERCA function in the animal model of type 1 diabetes. As expected, alloxan-treated rabbits displayed hyperglycemia within $24 \mathrm{~h}$ after injection, which persisted during the 3 week observation period (5.8 \pm 0.4 and $21.5 \pm 1.5$ $\mathrm{mM}$ at baseline and 3 week after alloxan injection, respectively; $\mathrm{n}=10, \mathrm{P}<0.05)$. In contrast with controls, alloxan-treated rabbits did gain weight slower. Although alloxan-treated rabbits were insulin deficient, they did not require insulin injections to survive; they remained alert and responsive during the observation period after the onset of diabetes. To record $\left[\mathrm{Ca}^{2+}\right]_{\mathrm{i}}$ transient, myocytes were stimulated at a constant frequency of $1 \mathrm{~Hz}$ through a pair of platinum electrodes. After stabilization period $\left[\mathrm{Ca}^{2+}\right]_{\mathrm{i}}$ transient as fluorescence signal, and contractile function as cell shortening were measured in steady-state condition. Groups were compared on percent scale, after taking the mean value of the healthy control cells as $100 \%$. Calcium transient morphology is summarized in Figure 7. Both $\mathrm{Ca}^{2+}$ transient amplitude and diastolic $\mathrm{Ca}^{2+}$ level, as reflected by Fluo-4 fluorescence signal, tended to be higher in cells

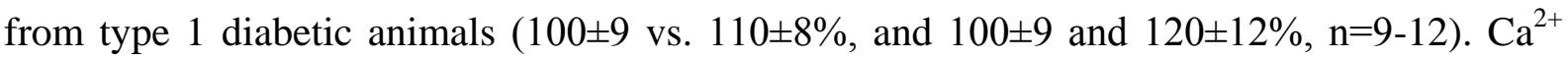
transient decay time (C) in diabetic myocytes was significantly larger in cells from diabetic animals compared to the healthy animals $(100 \pm 4,8$ and $121 \pm 6,5 \%, n=9-12)$. Despite the elevated $\mathrm{Ca}^{2+}$ transient, cell-shortening measurements (D) revealed a significant impairement in contraction function in diabetic cells $(100 \pm 7 \%$ and $72 \pm 11 \% \mathrm{n}=10)$. 

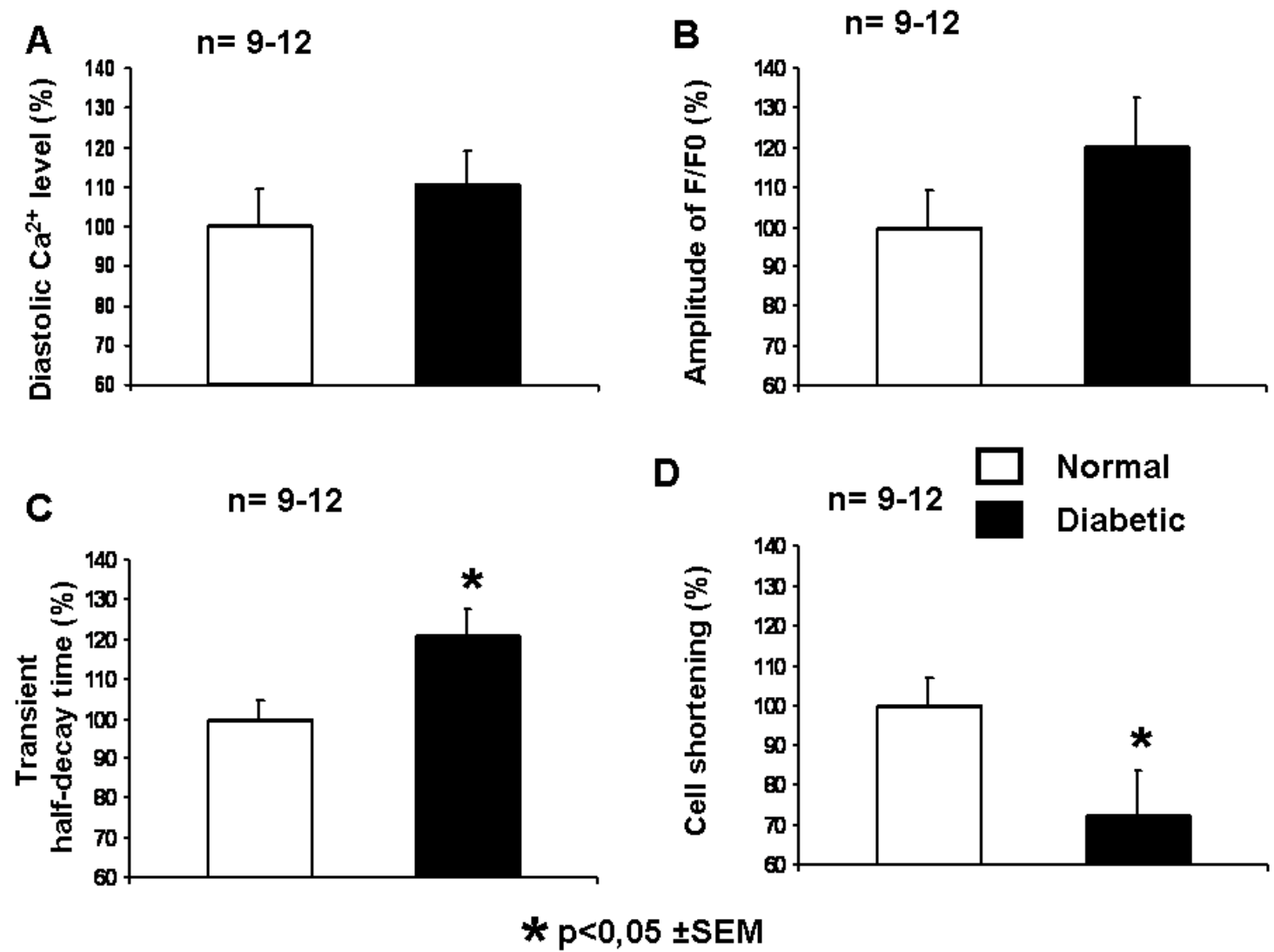

Figure 7 Differences in $\left[\mathrm{Ca}^{2+}\right]$ i transient and cell shortening of myocytes from control and experimental type1 diabetic rabbits. (B) amplitude of calcium transients, (A) diastolic calcium levels, (C) changes of calcium transient decay constant, and (D) cell shortening measurements Bars represent means \pm SEM, and $\mathrm{n}$ represents the number of experiments $(p<0,05)$.

\subsubsection{Comparison of the effect of partial NCX block by SEA0400 on intracellular $\mathrm{Ca}^{2+}$} transient and cell shortening in normal and diabetic rabbit myocytes

The myocytes from normal and alloxan-treated groups were field stimulated at a constant frequency of $1 \mathrm{~Hz}$ and superfused with normal Tyrode solution. After establishing steady-state contractions and $\left[\mathrm{Ca}^{2+}\right]_{\mathrm{i}}$ transients, the perfusion was switched to the solution containing $0.3 \mu \mathrm{M}$ of SEA0400, and a period of $5 \mathrm{~min}$ was allowed to develop full drug effect. Original recordings of the intracellular $\mathrm{Ca}^{2+}$ transients and cell shortening before and after administration of $0.3 \mu \mathrm{M}$ SEA0400 are presented in Figure 8. Results show that partial NCX block alters neither the amplitude of $\mathrm{Ca}^{2+}$ transient nor diastolic $\mathrm{Ca}^{2+}$ level. However, administration of SEA0400 resulted in an increased duration of half-decay time in diabetic myocytes but not in cells from healthy animals. Cell shortening showed an (Fig 8B) increased amplitude in both groups (Fig 8C-D) in response to SEA0400. It must be noted that these experiments were carried out using time matched experimental design, thus the effects of SEA0400 must be related to the spontaneous time dependent changes observed in the 
corresponding control group (ie both healthy and diabetic cell populations with and without SEA0400). In other words, we apply between subjects design instead of using within subject design, which results in considerably lower statistical power. However, in this way we can avoid false negative or positive effects that could be due to the spontaneous changes of the measured parameters during the time course of the experiments.
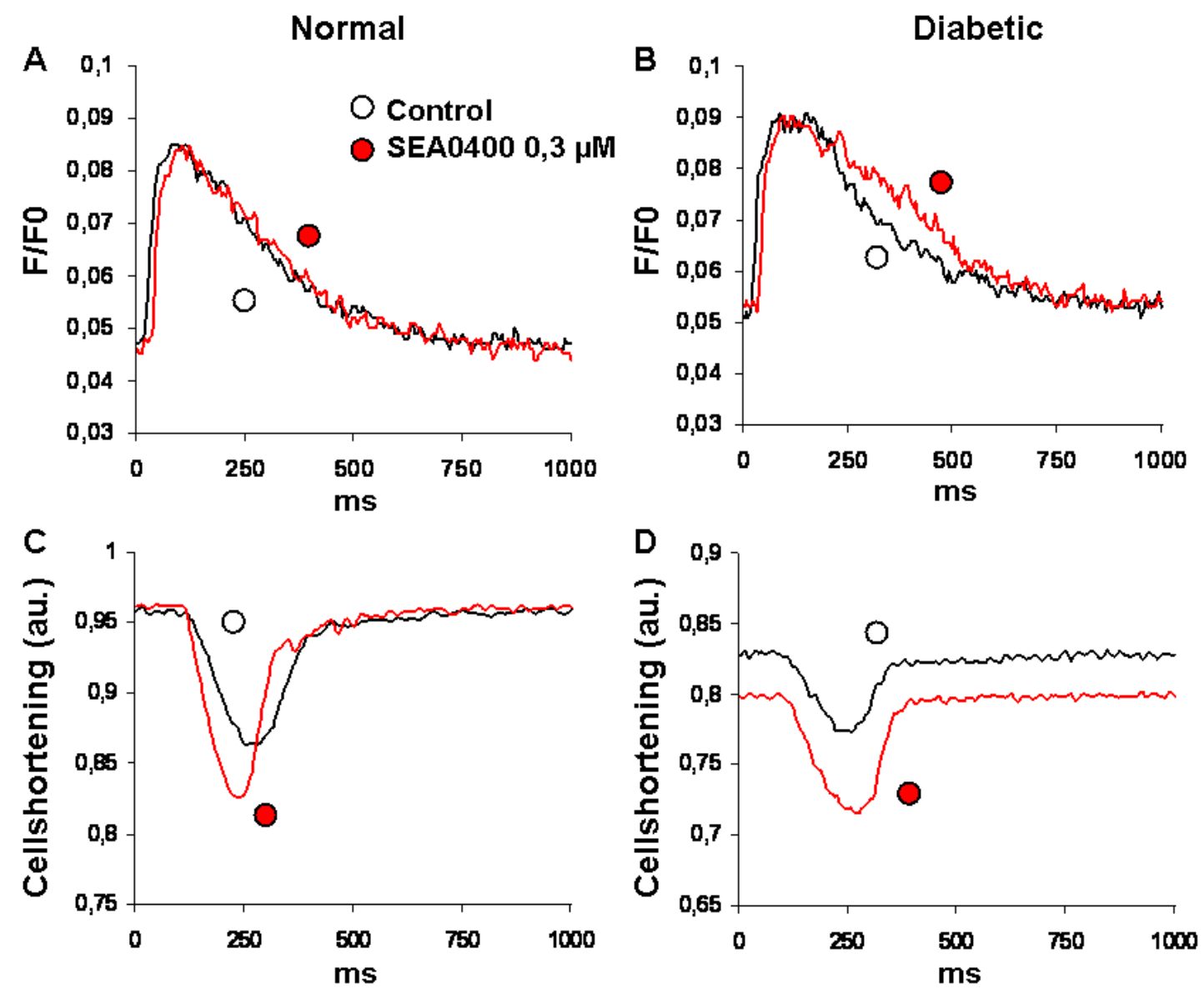

Figure 8 original recordings show the effect of partial NCX block on the intracellular $\mathrm{Ca}^{2+}$ transient and cell shortening in the presence of SEA0400 $(0,3 \mu \mathrm{M})$. (A, C) Cytosolic free $\left[\mathrm{Ca}^{2+}\right] \mathrm{i}$ and cell shortening recorded from normal (non-treated) rabbit ventricular myocyte before and after SEA0400 $(0,3 \mu \mathrm{M})$. B and D panels show results of a similar experiment using isolated myocytes from alloxan-treated rabbits. Stimulation frequency was constant $(1 \mathrm{~Hz})$. Cytosolic free $\mathrm{Ca}^{2+}$ concentration is expressed as a fluorescent ratio ( $\left.\mathrm{F} / \mathrm{F} 0\right)$, cell shortening is given in arbitrary units (AU). Recordings were made from the same cells before (open circle) and 5 min after (red filled circle) the application of SEA0400.

Figure 9 A-D summarizes the differing effects of SEA0400 in cells from healthy and diabetic animals according to the above considerations. While there were no effect on diastolic $\mathrm{Ca}^{2+}$ level in response to partial NCX inhibition (in normal: $-7,9 \pm 10,2 \%$ before and $-4,7 \pm 14,1 \%$ after, in diabetic: $-4,3 \pm 12,2 \%$ before and $4,2 \pm 13,9 \%$ after), the amplitude of the $\mathrm{Ca}^{2+}$ transient showed a moderate increase in the diabetic group after application of SEA0400 (normal: $2,9 \pm 8,4 \%$ before and $5,1 \pm 8,9 \%$ after, diabetic: $-1,9 \pm 8,4 \%$ before and $11 \pm 14,4 \%$ after). 
This was accompanied by a moderately increased amplitude of cell contraction as shown in Figure 9D contraction amplitude (normal: $-0,9+8,4 \%$ before and $22,7+3,9 \%$ after $\mathrm{p}=0,050$, diabetic: $-0,7+8,6 \%$ before and $15,3+15,2 \%$ after). In sharp contrast to these parallel changes of the $\mathrm{Ca}^{2+}$ transient and cell shortening in diabetic group, the increased cell contraction in response to SEA0400 occurred apparently without any underlying change in $\mathrm{Ca}^{2+}$ transient in the normal group (normal: $-2,9 \pm 8,4 \%$ before and $5,1 \pm 8,9 \%$ after). It is very hard to interpret this finding, because it is generally accepted that in normal healthy myocytes the increase of the contractile force should be, at least in part, the consequence of the elevated $\mathrm{Ca}^{2+}$ transient.
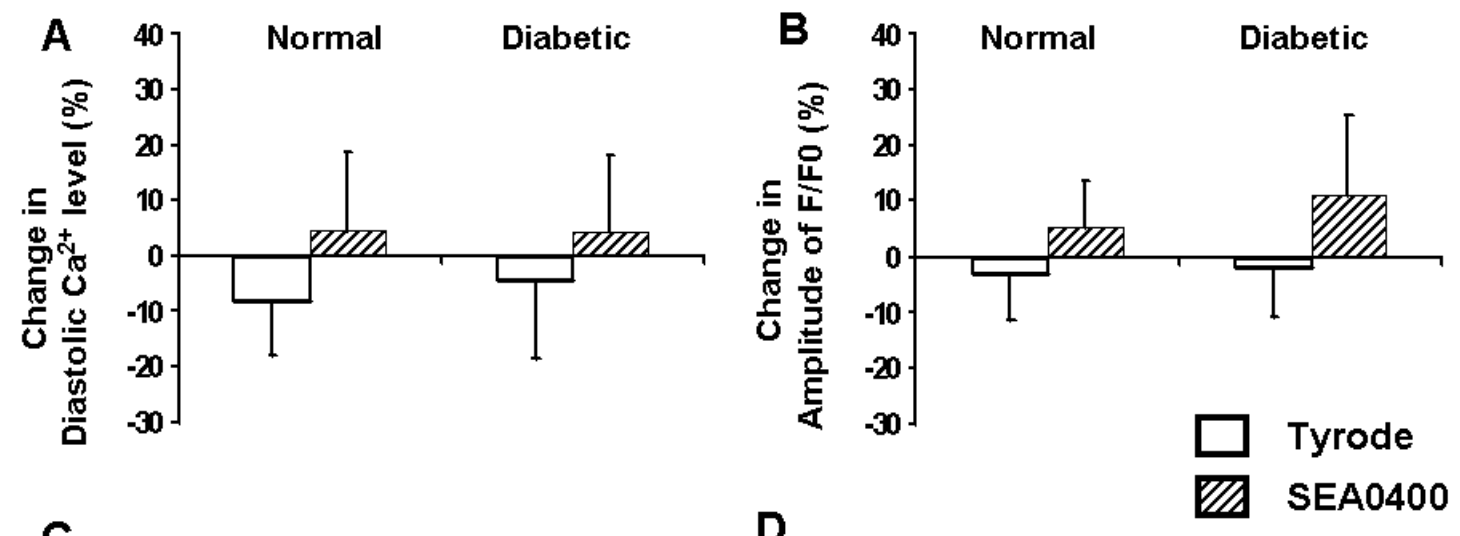

C
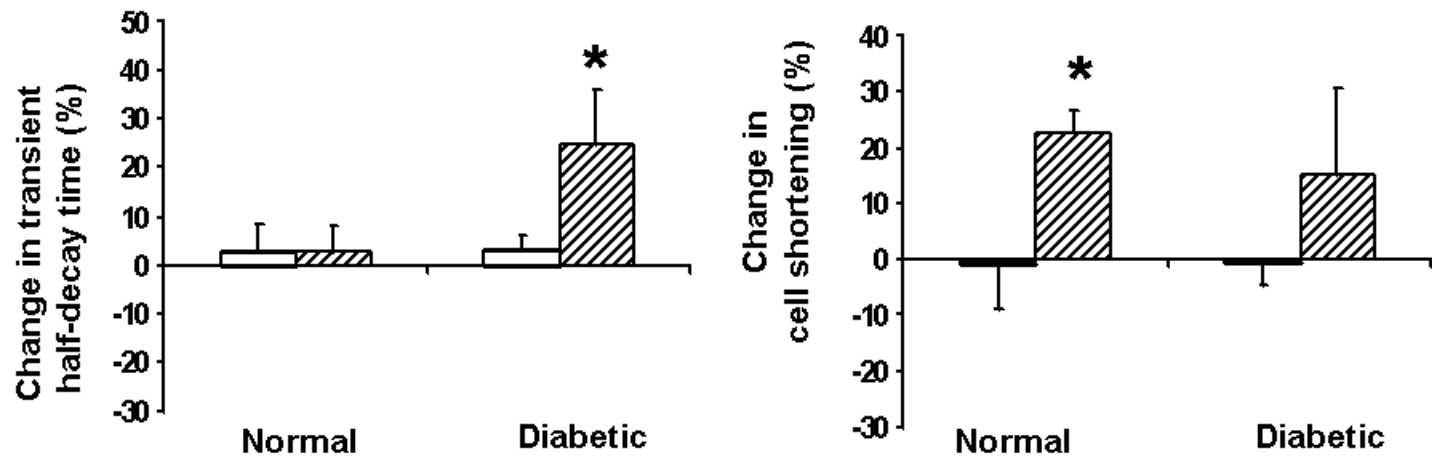

Figure 9. Average results of SEA0400 on transient parameters and cell shortening in field stimulated myocytes from simulated diabetic rabbit. A: Diastolic $\mathrm{Ca}^{2+}$ level, B: amplitude of $\left[\mathrm{Ca}^{2+}\right]_{\mathrm{i}}$ transient, $\mathrm{C}$ : half decay time of $\mathrm{Ca}^{2+}$ transient, D: cell shortening. Open (Tyrode) and filled (SEA0400) columns represent mean data \pm S.E.M obtained with the control $(n=9)$ or alloxan-treated $(n=10)$ groups. Asterisks indicate significant differences $(\mathrm{P}<0.05)$ between then $0,3 \mu \mathrm{M}$ SEA0400-treated and the Tyrode groups.

Although increased sensitivity to $\mathrm{Ca}^{2+}$ of the contractile machinery could be a possible explanation, it is hard to assume that this would occur after partial inhibition of NCX. Figure 9C shows that the mild increase of the $\mathrm{Ca}^{2+}$ transient after application of SEA0400 was also accompanied by a significant lengthening of the half decay time of $\mathrm{Ca}^{2+}$ transient $(103,1 \pm 2,6$ ms before and $124,7 \pm 11 \mathrm{~ms}$ after $\mathrm{p}=0,043, \mathrm{n}=5$ ). There was no similar effect in the normal healthy group $(102,7 \pm 5.6 \mathrm{~ms}$ before and $102,6 \pm 5,2 \mathrm{~ms}$ after, $\mathrm{n}=7)$, indicating again the altered consequences of NCX inhibition in the diabetic cells. 


\subsubsection{Analysis of the effect of rest decay in normal and diabetic cells}

As depicted in Figure 10 steady state kinetics show a much different time course in cells from diabetic animals. In this protocol cells were stimulated at $1 \mathrm{~Hz}$. Stimulation was stopped for 1 minute, after which again continued. In both groups the amplitude of the first $\mathrm{Ca}^{2+}$ transient following the rest period was higher than the following ones, indicating that there was no significant $\mathrm{Ca}^{2+}$ loss from the cell during the rest period (Fig10A,B). The smaller $2^{\text {nd }}$ and $3^{\text {rd }}$ transients indicate a temporary decrease in the SR $\mathrm{Ca}^{2+}$ load, as a consequence of increased $\mathrm{Ca}^{2+}$ extrusion during the first contraction cycle. However, the rest of the time course showed rather different characteristics. As seen in Fig 10C, compared to the healthy group, the refill of the SR lasted much longer in the diabetic group, because (1) at the end of the rest period the $\mathrm{SR} \mathrm{Ca}{ }^{2+}$ load (as reflected by the $\mathrm{Ca}^{2+}$ transient amplitude) was lower, and (2) the final steady state $\mathrm{Ca}^{2+}$ level was higher in this group (see also Fig. 7).

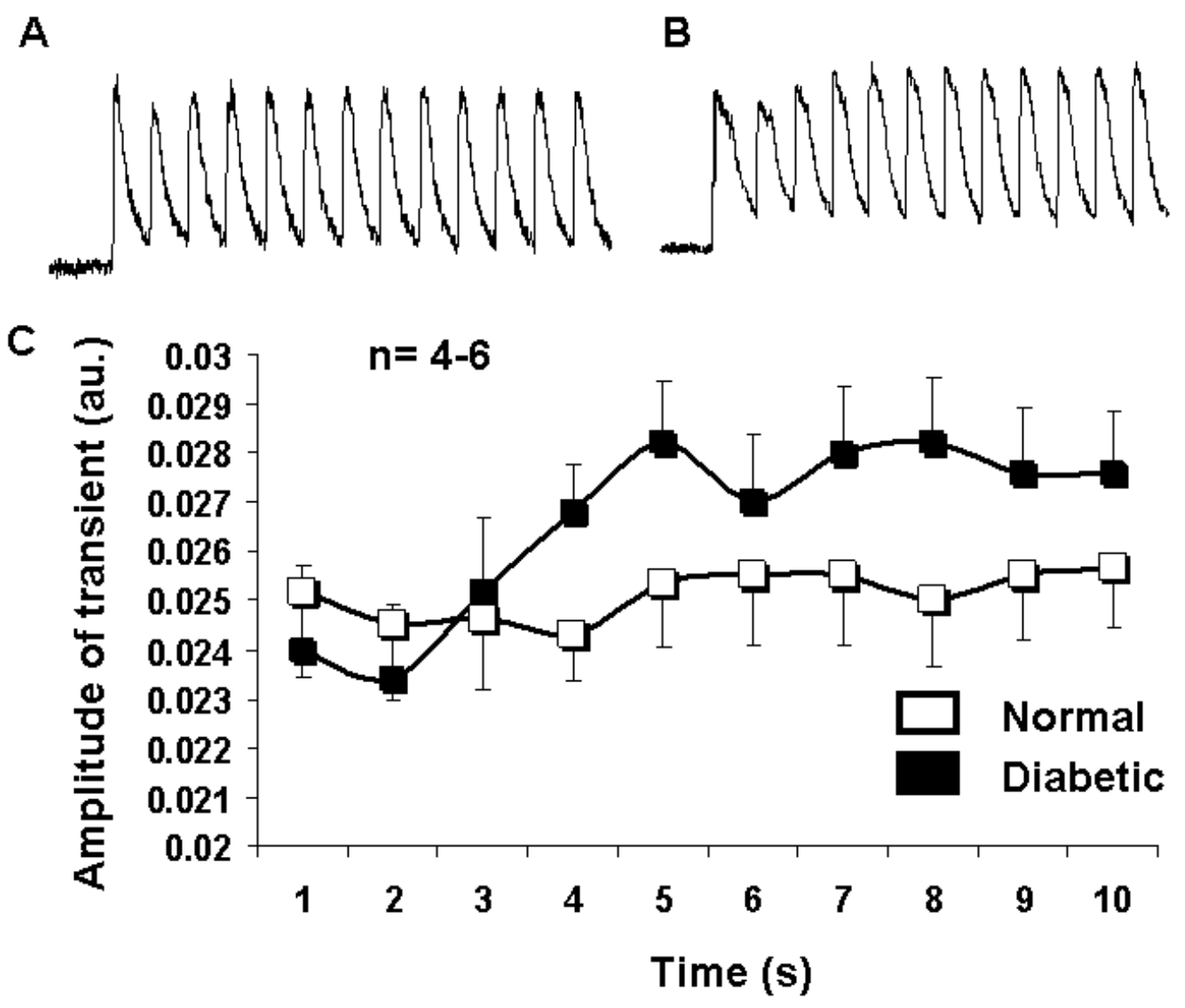

Figure 10. Effect of a pause period in pacing on intracellular free calcium concentrations and $\mathrm{Ca}^{2+}$ transient recovery in experimental diabetic myocytes. Representative recordings obtained from normal (A) and diabetic (B) rabbit myocytes under control conditions after 1 minute non-stimulated period by applying $1 \mathrm{~Hz}$ field stimulation. (C) Original recordings show the recovery from refractoriness under control conditions. Solid lines are the averages mean \pm SEM, $n=4-6$ ) 


\subsubsection{Effect of NCX inhibition on the rest decay protocol}

The rest decay protocol was repeated in the presence of SEA0400. Results, summarized in Figure 11 show, that while in the healthy group partial NCX inhibition with $0,3 \mu \mathrm{M}$ SEA0400 only slightly affected the recovery with a small decrease in the final SR $\mathrm{Ca}^{2+}$ load (the difference is increasing in time), it exerted a more pronounced effect on the diabetic group, where the whole curve was shifted down and the effect was greater in the first part of the recovery.

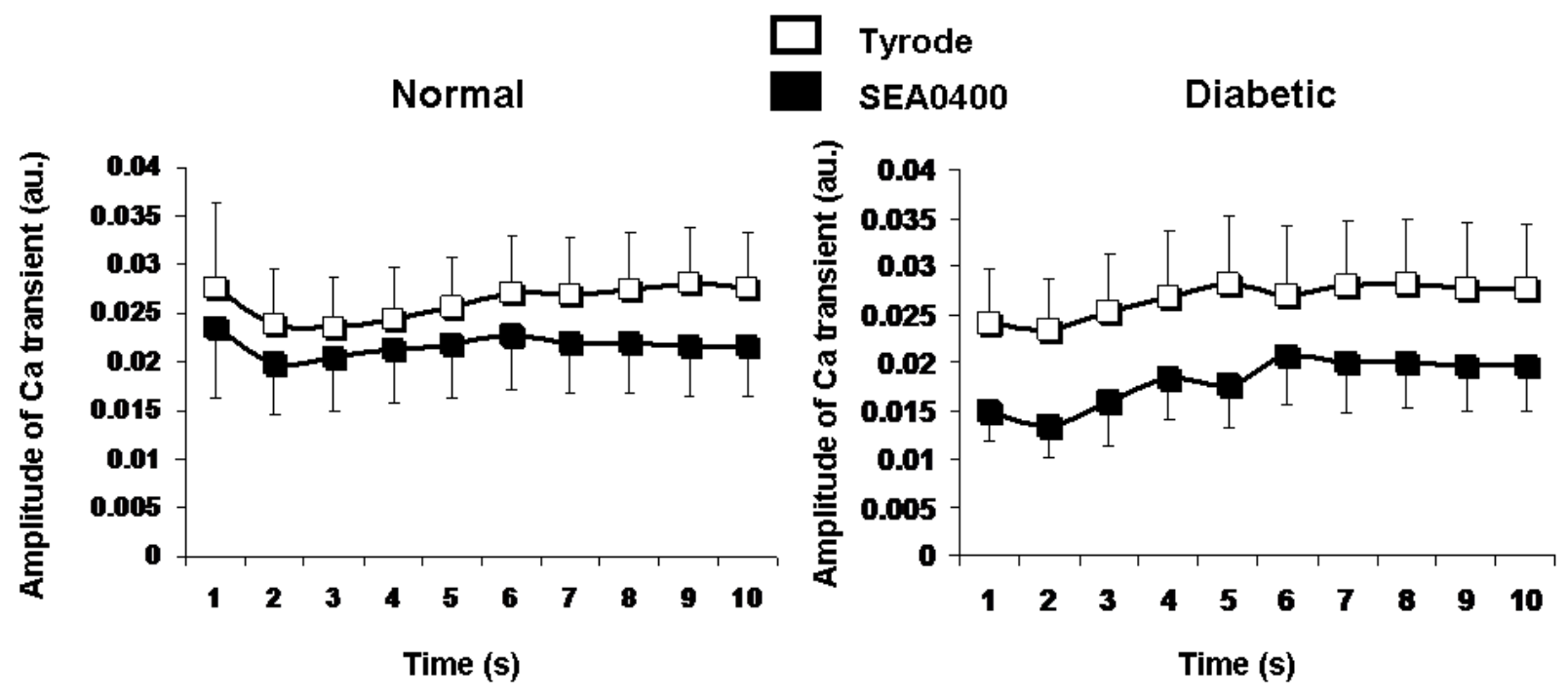

Figure 11. The effect of SEA0400 treatment on the recovery of the $\mathrm{Ca}^{2+}$ transient following a 1 minute rest period. Averaged data for untreated ( $\square$ ) and treated ( ) (0.3 $\mu \mathrm{M}$ SEA0400) cardiomyocytes from healthy (left panel) and diabetic (right panel) rabbits. (Mean \pm SEM, $(n=5-7)$.

These results indicate, that though there was only a slight difference between the 1 st $\mathrm{Ca}^{2+}$ transients during the rest period and/or the refill (see Fig 10), the net $\mathrm{Ca}^{2+}$ flux via NCX, as revealed following partial NCX inhibition, is significantly altered in diabetic cells.

\subsubsection{Frequency dependent changes in the $\mathrm{Ca}^{2+}$ handling}

Frequency dependent alterations of the myocardial $\mathrm{Ca}^{2+}$ handling are characteristic in different species and cardiac diseases. We tested the possibility that diabetic alterations are accompanied with changes in the frequency dependence of the $\mathrm{Ca}^{2+}$ handling. After increasing the stimulation frequency from 0.5 to $2 \mathrm{~Hz}$ in our experiments we have found a mild elevation in the diastolic $\mathrm{Ca}^{2+}$ level in both the normal and diabetic group (Fig. 12). However, in contrast with our expectations, with the increasing frequency the $\mathrm{Ca}^{2+}$ transient amplitude increased neither in normal nor in diabetic cells, indicating that in our experiments the increased $\mathrm{Ca}^{2+}$ transient was purely due to the elevated diastolic $\mathrm{Ca}^{2+}$. Similarly to the 
earlier protocol, we also repeated the frequency dependent test with and without SEA0400 by applying time matched experiments.
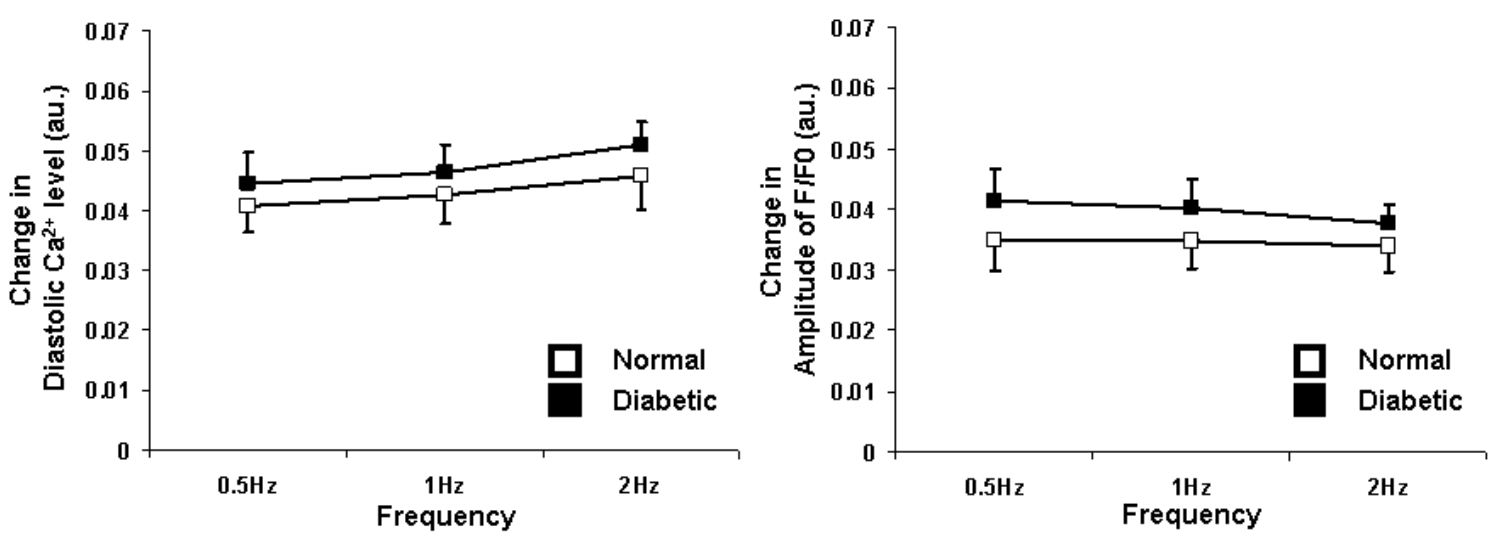

Figure 12 Frequency dependent changes in Normal and Diabetic rabbit myocytes. This figure shows that the response of the diastolic $\mathrm{Ca}^{2+}$ level and transient aplitude. The effect of increasing pacing frequency (from 0,5 to $2 \mathrm{~Hz})$ increased the diastolic $\left[\mathrm{Ca}^{2+}\right]_{\mathrm{i}}$ and decreased amplitude of $\left[\mathrm{Ca}^{2+}\right]_{\mathrm{i}}$ transient in both studied groups.
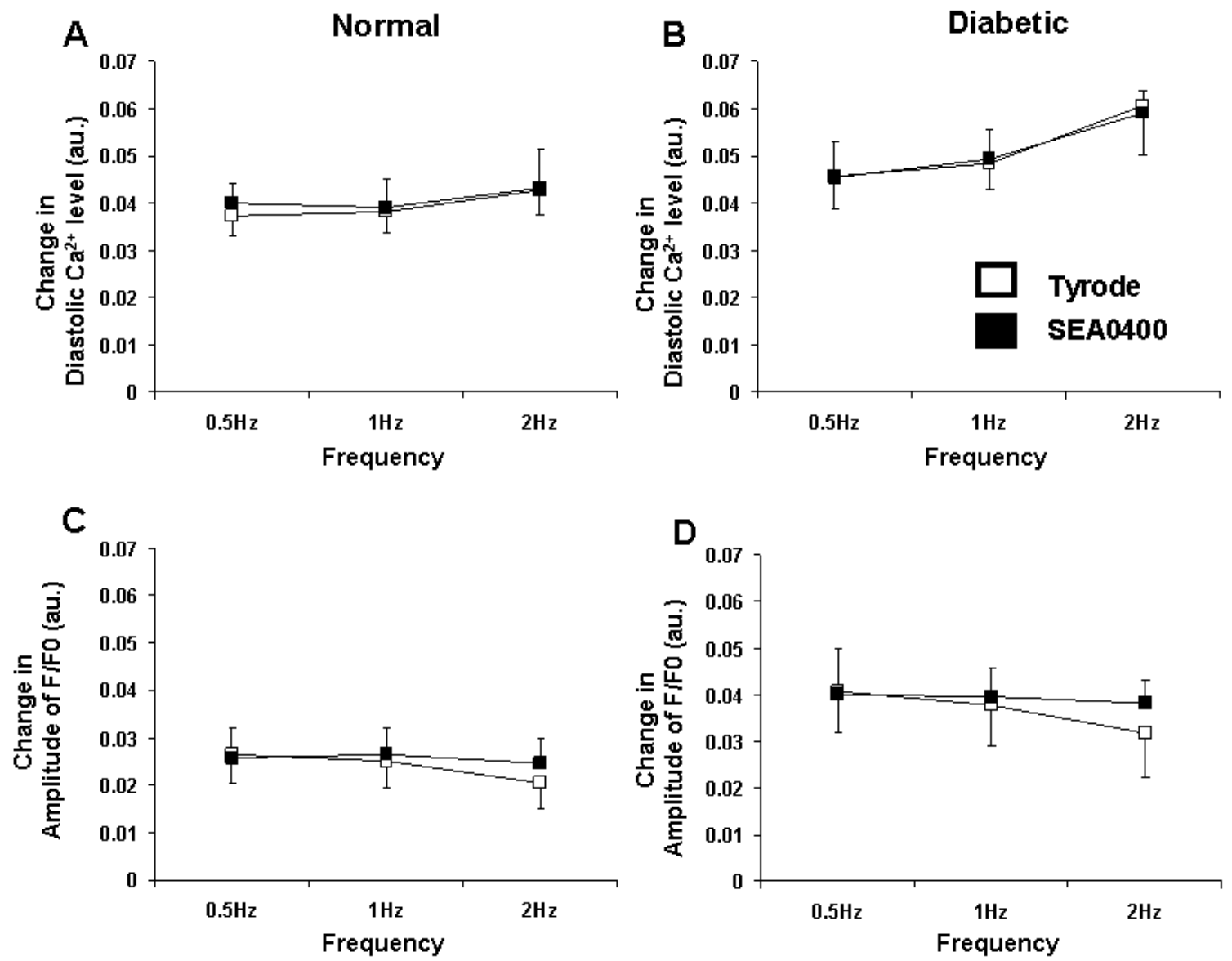

Figure 13 This figure shows frequency dependent effect of SEA0400 in diastolic calcium levels (A, B) and amplitude of calcium transients (C, D). In $\mathrm{Ca}^{2+}$ transient amplitude were found that efficiency of SEA0400 to be dependent on the rates of pacing. Panel C and D shows SEA0400 have a moderately but higher efficiency under $2 \mathrm{~Hz}$ pacing in both studied group.

As shown in Figure 13 application of SEA0400 did not cause any change in the frequency dependent behavior of the diastolic $\mathrm{Ca}^{2+}$ level in neither of the groups, while it tended to 
increase the amplitude of $\mathrm{Ca}^{2+}$ transient in both groups at $2 \mathrm{~Hz}$, with a bigger effect in case of diabetic cells, which is in line with the results of the protocol in Figure 9. In contrast, $\mathrm{Ca}^{2+}$ transient amplitude after SEA0400 tended to decrease in the diabetic group.

\subsection{Herpesvirus-mediated delivery of a genetically encoded fluorescent $\mathrm{Ca}^{2+}$ sensor to canine cardiomyocytes.}

\subsubsection{Morphological changes of cultured cardiomyocytes}

Using the described method for isolation of adult dog left ventricular myocytes, we routinely obtained a high yield (more than 80\%) and high (more than 80\%) percentage of rodshaped myocytes, that were suitable not only for acute functional studies but, more importantly, for short-term culture and gene transfer. Figure 15a shows a trans-illumination image of freshly isolated and 1-day-old cultured cardiomyocytes from the left ventricle. To establish optimal surviving conditions several culture conditions were tested, based on microscopic evaluation of changes in cellular morphology during four days of culture. Cultured cells were used 1-3 days after isolation. During this period, visible minor changes in cell shape and cross-striation could be observed. Figure 15b shows representative photographs of canine myocytes over time in primary culture. Features typical of acutely isolated (Day 0) cells were the rod shape with rectangular stepped ends and clear cross-striations. After 1 day (Day 1) in culture, the cells were still rod-shaped with clear cross-striations; however, the ends of the cells started to become slightly rounded in appearance. After 3 days (Day 3) in culture, cells remained rod-shaped and cross-striated, and the main change was that cell ends became progressively more rounded (see Table 1 for cell survival rates).

\begin{tabular}{llrrrrrr}
\hline & & Day 0 & Day 1 & Day 2 & Day 3 & Day 4 & Day 5 \\
\hline Control & $\begin{array}{l}\text { Average } \\
(\%):\end{array}$ & 100 & 60,0 & 44,9 & 4,3 & 2,8 & 2,2 \\
& $\begin{array}{l}\text { Standard } \\
\text { error: }\end{array}$ & & 6,0 & 8,4 & 0,5 & 0,3 & 0,3 \\
Virus & $\begin{array}{l}\text { Average } \\
\text { infected }\end{array}$ & 100 & 85,5 & 69,2 & 12,8 & 3,1 & 1,3 \\
& $\begin{array}{l}\text { Standard } \\
\text { error: }\end{array}$ & & 4,7 & 9,3 & 3,7 & 1,5 & 0,6 \\
\hline
\end{tabular}

Table 1 This table shows the survival of non-infected and virally infected cells from day 0 to day 5 . It can be seen that virally infected cells exhibit slightly better survival than non-infected cells, for which the reason remains to be ascertained. 

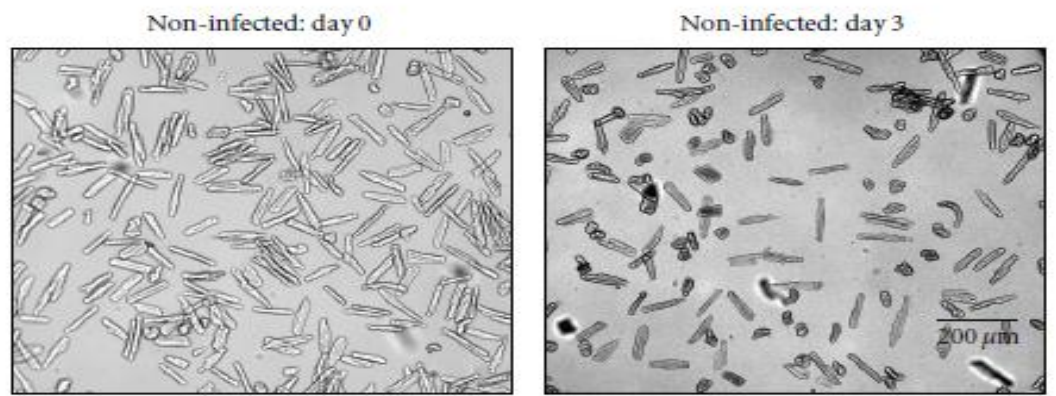

(a)
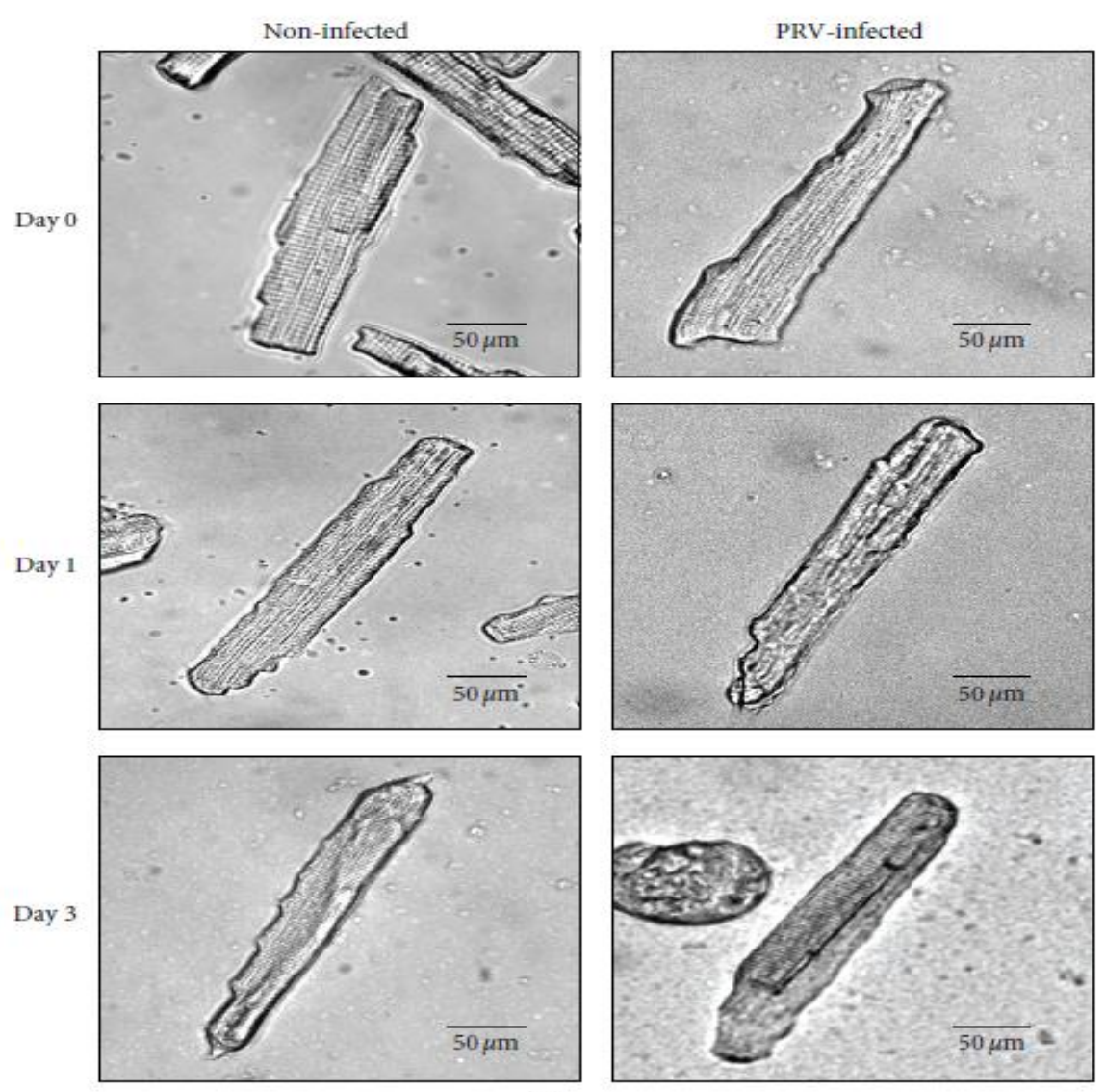

(b)

Figure 15: Representative low and high magnification trans-illumination of adult dog myocytes after isolation (day 0) and 1-3 days of culture (day 1, day 3). (a) shows the yield of the myocytes before and one day after culturing and infection. The high-magnification transillumination (b) shows the morphology of adult dog myocytes after isolation (day 0) and 1-3 day of culture (day 1, day 3) and the morphological changes of living cells, versus the culturing time from non-infected (right) and the virus-infected groups (left). After one day plated myocytes more than $80 \%$ displayed a rod-shaped morphology and healthy cross-striation. After 3 days (day 3 ) in culture, cells remained rod-shaped and partially cross-striated, and the main change was that cell ends became progressively more rounded.

\subsubsection{Efficacy of virus infection in cultured cardiomyocytes}

Survival rates were found to be dependent on the isolation procedure, density of the attached myocytes and the applied virus titer. Intriguingly, a higher total number of viable cells were observed on the laminin-coated surfaces after plating in CCTI supplemented 
medium. As respective panels of Fig 15 and 16 (upper panel) shows, even after three days, the cell culture contained a substantial number of good quality cells both in the control and virus infected groups. Surprisingly, a moderately but consistently higher cell survival rate was found in virus infected groups as compared to non-infected groups (not shown). The infection efficiency was found to be $100 \%$, that is $24 \mathrm{~h}$ post-infection every surviving cells emitted fluorescent signals provided that high dose of virus was used for the infection (Fig 16 bottom panel).
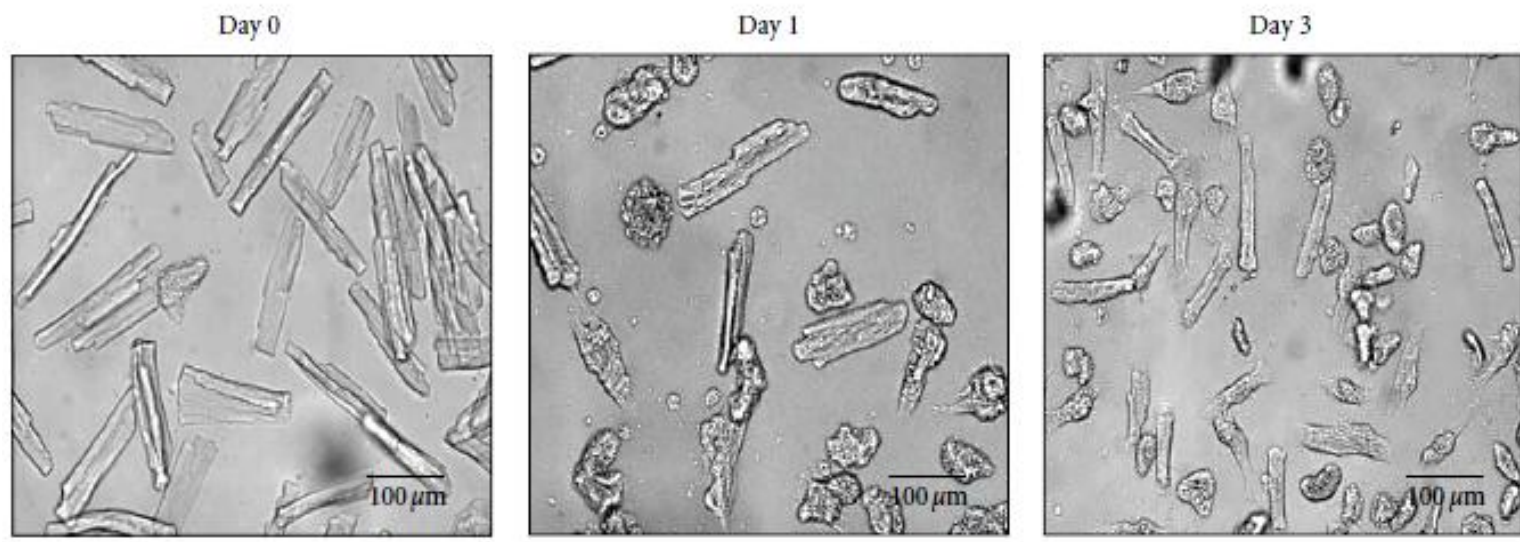

(a)
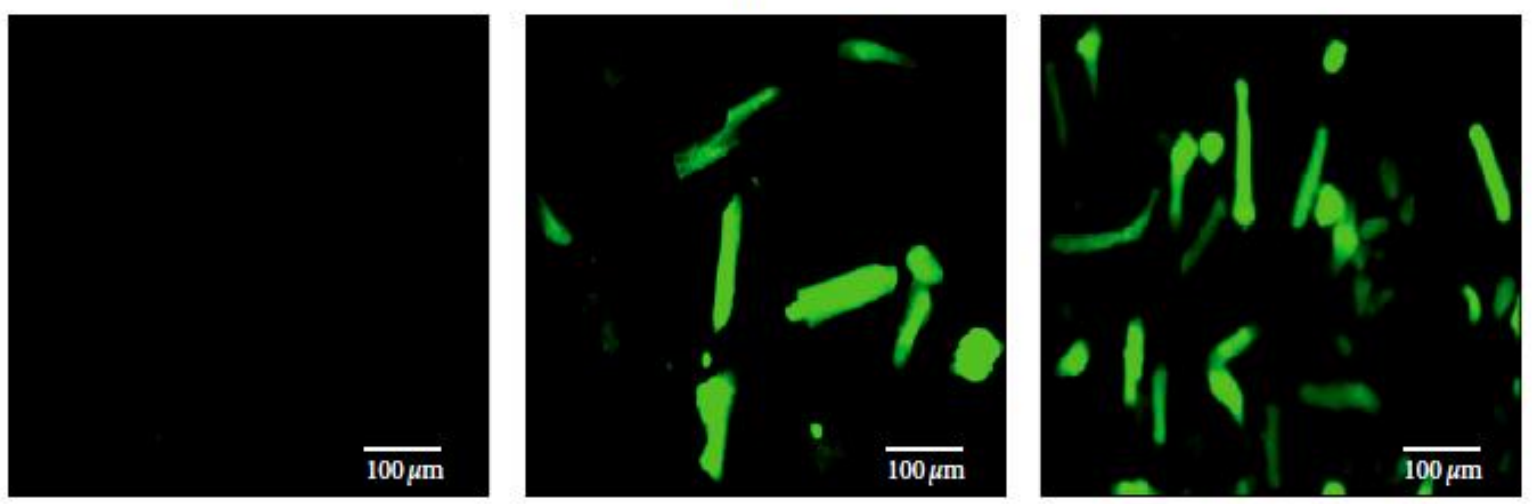

(b)

Figure 16: (a) Representative light and (b) fluorescent microscopic images of cell culture, before and after 1 day and 3 days of virus infection. Expression of recombinant pseudorabies-viral troponeon transgenes appeared on high level in cultured adult dog ventricular myocytes. The isolation of adult dog left ventricular myocytes yielded more than $80 \%$ living cells. After three days the troponeon expression and the physiological features of survival myocytes was appropriate for the physiological studies.

\subsubsection{Whole-cell patch-clamp recordings}

The whole-cell configuration of the patch-clamp technique was used to record the transient outward $I_{\text {to }}$ current. $I_{\text {to }}$ was chosen as a physiological assay because it is a large current that can be measured relatively easily in isolated canine ventricular myocytes. The 
current was activated by $300 \mathrm{~ms}$ long depolarizing voltage pulses from the holding potential of $-90 \mathrm{mV}$ to test potentials ranging from 0 to ${ }^{+} 60 \mathrm{mV}$ with a pulse frequency of $0.33 \mathrm{~Hz}$.

The amplitude of $\mathrm{I}_{\mathrm{to}}$ was measured as the difference between the peak and the sustained current at the end of the voltage pulse. Figures 17A shows typical recordings of $\mathrm{I}_{\text {to }}$ measured after one (Day 1) and three days (Day 3) of culture either in control (top panels) or virus infected cells (bottom).
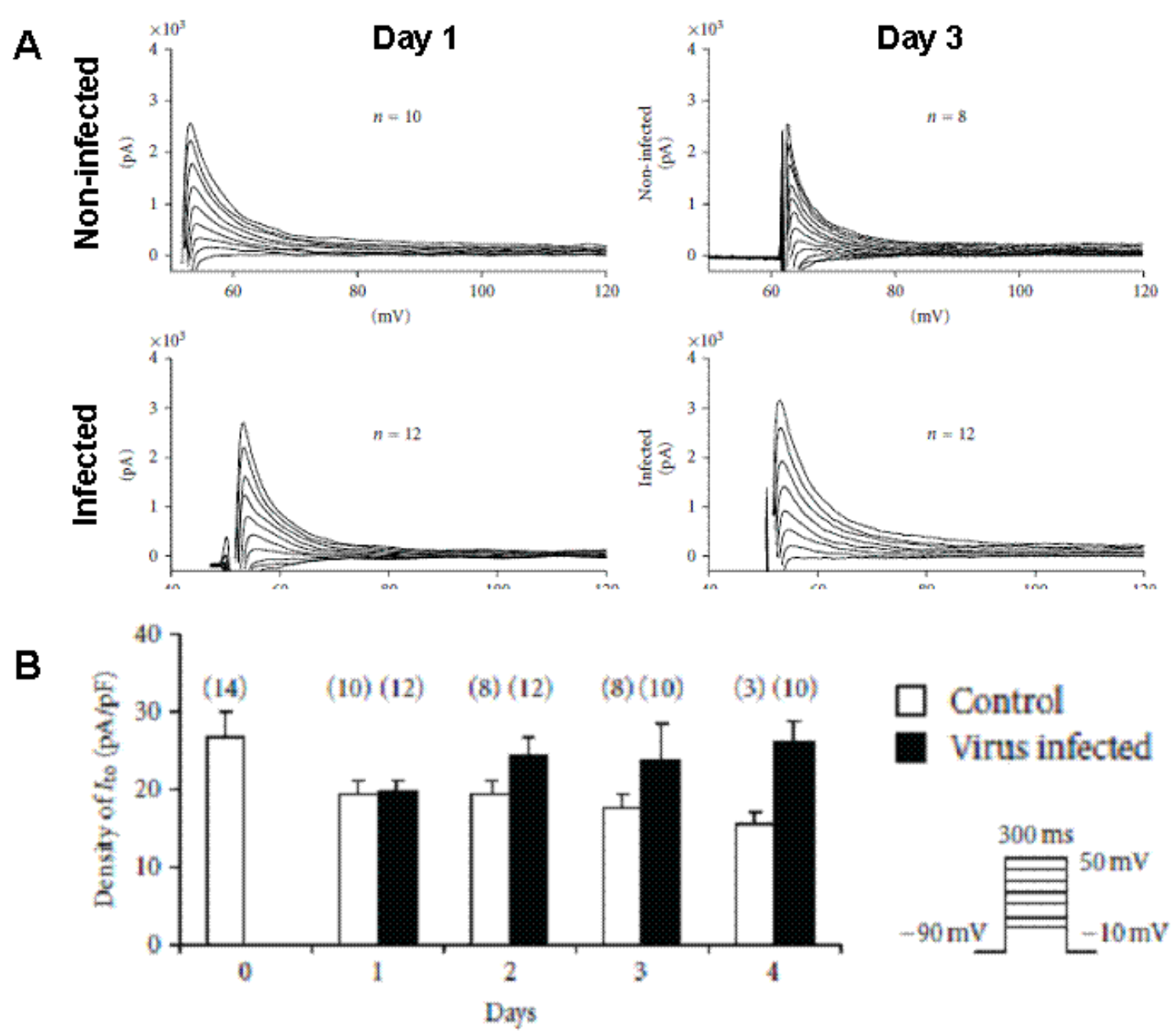

Figure 17: (A) Transient outward $\mathrm{K}$ current $\left(\mathrm{I}_{\mathrm{to}}\right)$ recordings from control and from virus-infected myocytes after 1 and 3 days of culture. Inset shows applied voltage protocol. (B) shows the Ito current densities from control and from virus-infected myocytes after 1 to 4 days long culture. Data represent means \pm SEM, and n represents the number of cells.

Figure 17B summarizes all $\mathrm{I}_{\mathrm{to}}$ measurements performed after 0-4 days of culture in both groups. As the corresponding panels of Figure 17 show, the amplitude of the $\mathrm{I}_{\text {to }}$ was reduced by less than $10 \%$ in virus infected myocytes (VM) compared to control non-infected cells (CM) even after 4 elapsed days. The $\mathrm{I}_{\text {to }}$ kinetics (activation and inactivation properties) were 
also not altered significantly by the virus infection. Moreover current amplitude was somewhat larger in PRV-infected cells compared to that of observed in control cells. Mean $\mathrm{I}_{\text {to }}$ density (Fig. 17B) was similar for CM and VM cells after 1 day. The $\mathrm{I}_{\text {to }}$ current density in VM changed in four days from $19.6 \pm 1.4$ to $24.6 \pm 2.6 \mathrm{pA} / \mathrm{pF}$ ( $\mathrm{n}=10-12)$, which corresponds well with that observed in $\mathrm{CM}$ (from $19.3 \pm 2.1$ to $17.1 \pm 1.5 \mathrm{pA} / \mathrm{pF}, \mathrm{n}=8-10$ ). Although mean $\mathrm{I}_{\text {to }}$ density of several-day-old $(2,3,4)$ cultured myocytes was significantly larger in VM than CM.

\subsubsection{Parameters of intracellular $\mathrm{Ca}^{2+}$ transients and contractility in PRV-infected myocytes}

Myocytes were stimulated at a constant frequency of $1 \mathrm{~Hz}$. Similar to the $\mathrm{I}_{\text {to }}$ measurements, steady-state $\mathrm{Ca}^{2+}$ transient and contractile function (cell shortening) were measured and compared on a daily basis, both in the infected and the control cell populations. Original recordings of $\mathrm{Ca}^{2+}$ i transients and cell shortening before and after virus infection are presented in Figure 18.

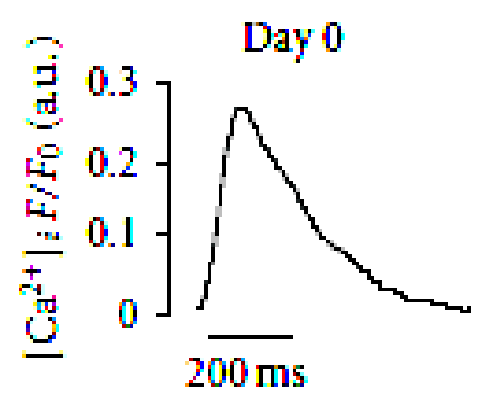

Day 1

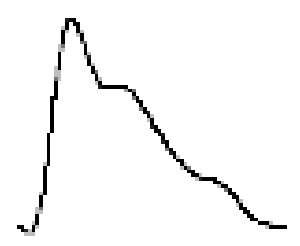

(a)

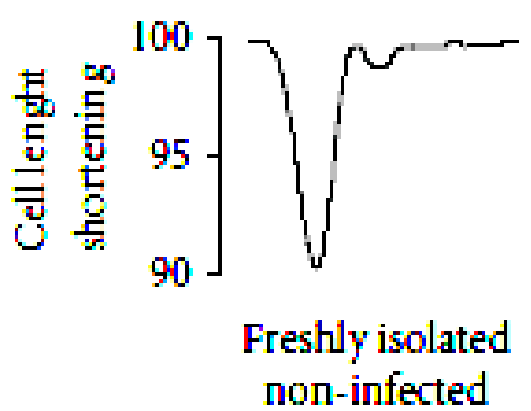

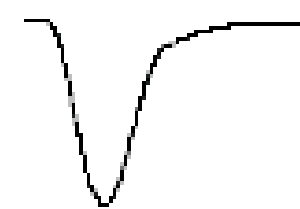

PRV-infected
Day 3
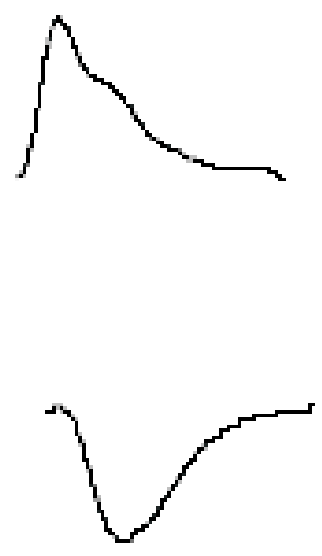

PRV-infected

(b)

Figure 18: Original $\mathrm{Ca}^{2+}$ transients and cell shortening recording in cardiomyocytes cultured for 1 and 3 days. The top panel shows the $\mathrm{Ca}^{2+}$ transients and bottom panel the parallel changes in cell length. 
The kinetics of the $\mathrm{Ca}^{2+}{ }_{\mathrm{i}}$ transient was rather distorted in culture, but did not significantly alter following viral infection. As summarized in Figure 19, we did not find statistically significant difference between the two groups in either the amplitude of $\mathrm{Ca}^{2+}$ transient (a) or the diastolic $\mathrm{Ca}^{2+}$ levels (b). Moreover, the decay time of the $\mathrm{Ca}^{2+}$ transient was significantly longer in the non-infected myocytes than in the virus infected group (c) after two or three days in culture. Conversely, in the virus-infected groups decay time was similar to that in freshly isolated cells. These results suggest that the non-infected cell population may have lost some of their calcium removal mechanism. The cell-shortening measurements (d) show a significant decline in non-infected cell culture after 1 and 3 days.

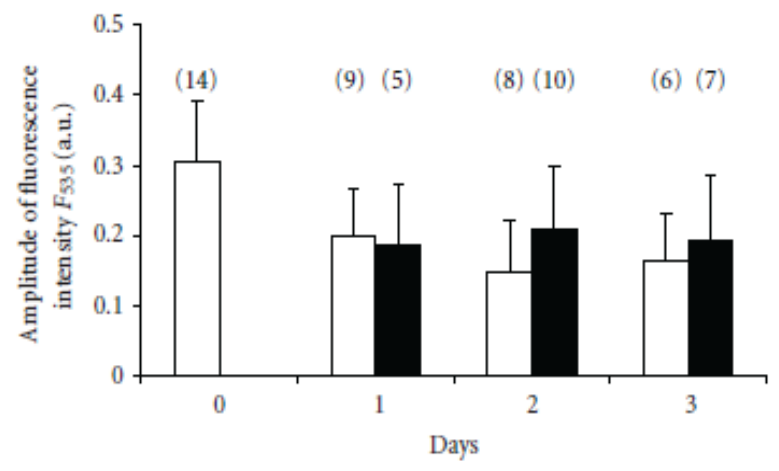

(a)

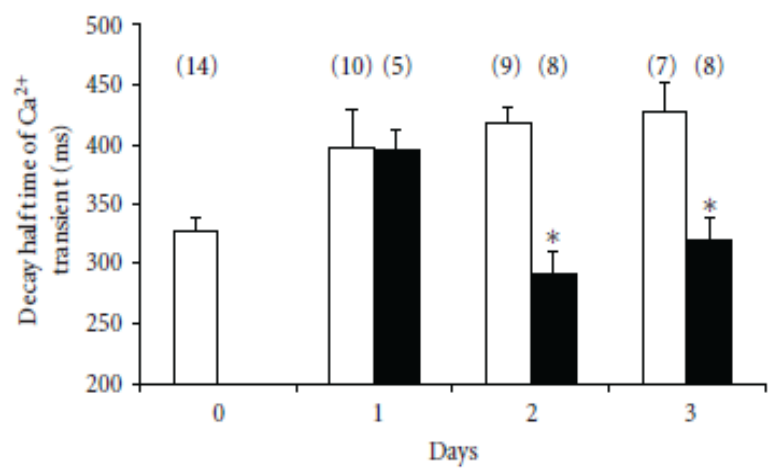

$\square$ Control

Infected

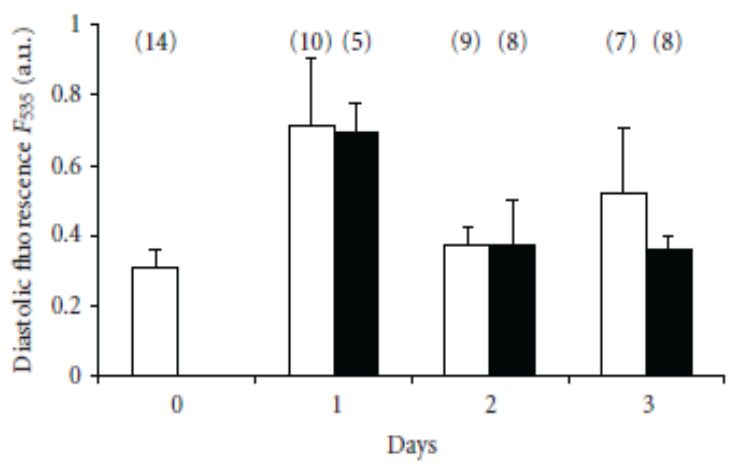

(b)

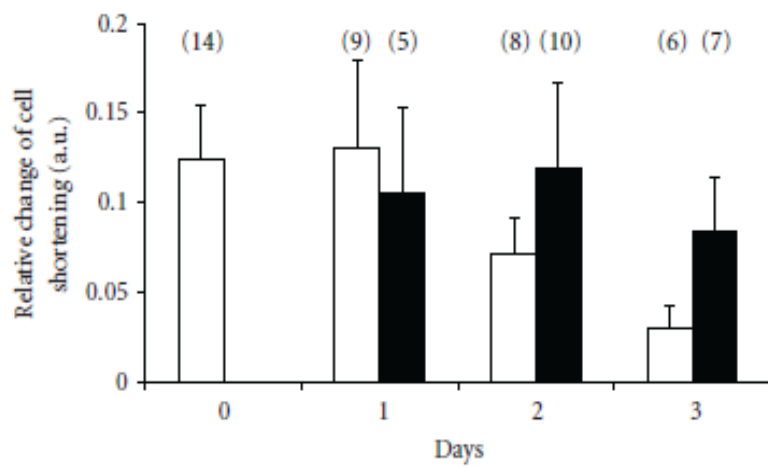

$\square$ Control

Infected

(c)

(d)

Figure 19: This figure shows several parameters of intracellular free calcium transient such as (a) amplitude of calcium transients, (b) diastolic calcium levels, (c) changes of calcium transient decay constant, and (d) cellshortening measurements from recordings from control and from virus infected myocytes after 1 to 3 days long culture. Bars represent means \pm SEM, and $n$ represents the number of experiments. 


\subsubsection{Functionality of FRET-based calcium sensor}

Freshly isolated ventricular myocytes were infected with the virus following $4 \mathrm{~h}$ plating and fluorescence could already be detected within $16 \mathrm{~h}$. The functionality of the transferred gene was verified by monitoring $\left[\mathrm{Ca}^{2+}\right]_{\mathrm{i}}$. Figure 20 shows two typical fluorescence signal emissions measured in troponenon-expressed cells obtained at $485 \mathrm{~nm}$ and $535 \mathrm{~nm}$ excitation (upper panel). The lower panel shows the ratio of the citrine and CFP emitted signals representing the changes of the $\left[\mathrm{Ca}^{2+}\right]_{\mathrm{i}}$ levels in the studied cells. This measurement clearly shows that virally-encoded troponenon retained its ability of indicating $\left[\mathrm{Ca}^{2+}\right]_{\mathrm{i}}$ levels in cardiomyocytes.

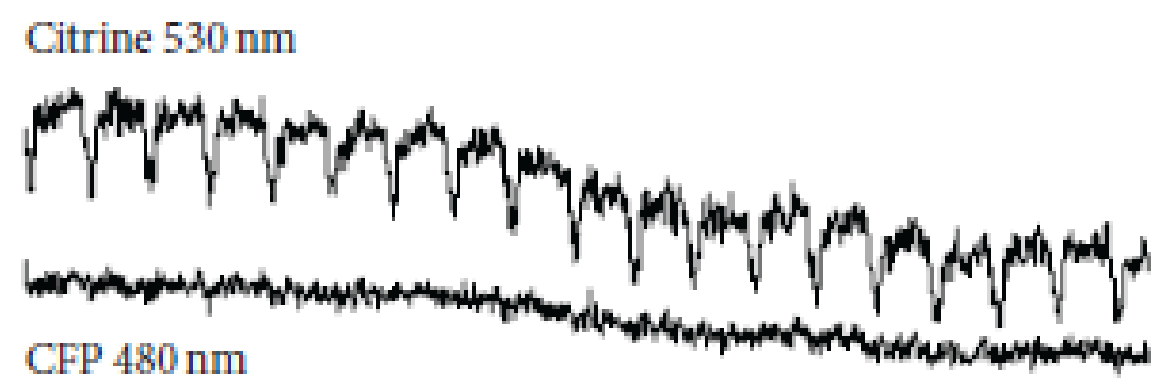

(a)

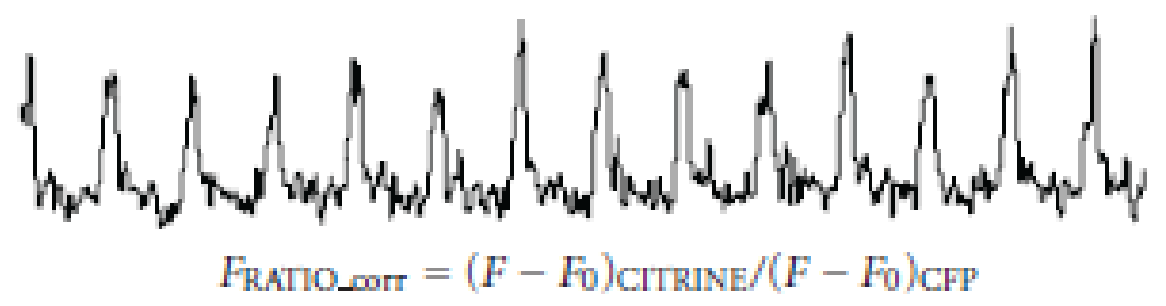

(b)

Figure 20: (a) Original recordings from cells expressed troponeon at the excitation wavelength of (a) 485 and $535 \mathrm{~nm}$ and (b) the characterized calcium transient by ratio of the fluorescence intensity (FCITRINE 535 / FCFP 485) from one day after infection. 


\section{DISCUSSION}

\subsection{New challenges in the field of $\mathrm{Ca}^{2+}$ signaling research}

It is well established that the $\mathrm{Ca}^{2+}$ ion has many important functions in living organisms in all fields of biology. It is not only an effector for vital cell functions such as cell contraction or exocitosis, but also plays crucial role in regulation of activity of metabolic enzyme systems and many signaling pathways [4]. Specifically in cardiomyocytes, since the early experiments demonstrating vital role for $\mathrm{Ca}^{2+}$ in excitation contraction coupling, there have been numerous discoveries regarding additional important functions for $\mathrm{Ca}^{2+}$ in subcellular signaling [2]. The introduction of $\mathrm{Ca}^{2+}$-sensitive fluorescent dyes more than twenty years ago and their permanent improvement [10] enabled investigators to gain unprecedented insights into the mechanisms of cellular signalling. The dynamics of $\left[\mathrm{Ca}^{2+}\right]$ changes at the whole cell level and in well-defined subcellular compartments in excitable cells during the course of membrane depolarization can now be much better understood in the context of disease processes such as cardiac arrhythmias and heart failure or diabetes.

In the living cells $\mathrm{Ca}^{2+}$ ion has a unique feature that it exerts multiple actions even within the same cell at the same time, depending on type of receptors or enzymes present in the cell. Furthermore, recent research underlines that in addition to multiple functions, spatial and temporal separation of local $\mathrm{Ca}^{2+}$ signals even within the same cytosolic compartment may be crucial in normal cellular function [42]. Indeed, it has been shown that disintegration of this complex spatiotemporal signaling system is characteristic during development of cardiac diseases [43], which emphasizes the needs of a more specific and targeted detection of local $\mathrm{Ca}^{2+}$ signals, in order to understand disease process in cardiac myocytes and also to explore new potential therapeutic targets. In this field, application of the FRET based methods can provide us with a useful tool in the Ca signaling research.

\subsection{Effect of SEA0400 on caffeine induced $\mathrm{Ca}^{2+}$ transients in canine cardiomyocytes: validation of SEA0400 as a tool to study the $\mathrm{Ca}^{2+}$ homeostasis}

Earlier reports on the effect of SEA0400 on $\mathrm{Ca}^{2+}$ handling [41, 44-46] are nonuniform and in some cases the findings are unexpected. These controversies may be due to speciesspecific differences in $\mathrm{Ca}^{2+}$ homeostasis and $\mathrm{Ca}^{2+}$ handling (i.e. the relative role of NCX in the maintenance of physiological $\mathrm{Ca}^{2+}$ levels), or due to inherent properties of SEA0400. For example, earlier studies [41] show that SEA0400 may have different efficacy in inhibiting NCX depending on the intracellular ionic composition. Specifically, high intracellular $\mathrm{Ca}^{2+}$ 
has been shown to counteract the blocking effect of SEA0400 on NCX [47]. These results may question the use of SEA0400 as an applicable tool in the $\mathrm{Ca}^{2+}$ handling research. Therefore, in our first experiments we characterized the NCX inhibiting effect of SEA0400 in an experiment where a high and long lasting intracellular $\mathrm{Ca}^{2+}$ level is achieved by application of $10 \mathrm{mM}$ caffeine. In this experimental setting the extrusion of $\mathrm{Ca}^{2+}$ from the cell is achieved only via the NCX, thus in this model the activity of NCX can be studied accurately. Under these conditions, inverse $\mathrm{Ca}^{2+}$ dependent NCX inhibiting effect of SEA0400 can be assumed to be maximal, thus in the experiments on the diabetic rabbit cells the actual degree of NCX block is presumably at least as large as in this caffeine experiment. According to our results, the effect of $1 \mu \mathrm{M}$ SEA0400 on the rate of decay of the caffeine-induced $\mathrm{Ca}^{2+}$ transient was only a fraction of that observed with $10 \mathrm{mM} \mathrm{NiCl}_{2}(20 \%)$ These results suggest that the NCXblocking effect of SEA0400 may be relatively moderate when $\left[\mathrm{Ca}^{2+}\right]_{\mathrm{i}}$ is elevated. It must be noted that weak inhibition of NCX in our experiments is not necessarily a disadvantage, because higher degree of inhibition can easily result in accumulation of $\mathrm{Ca}^{2+}$ inside the cell, which would lead to cell hypercontraction or cell death, especially in case of cells from diabetic animals, where the $\mathrm{Ca}^{2+}$ homeostasis is already compromised.

\subsubsection{Disturbed $\mathrm{Ca}^{2+}$ handling in type 1 diabetes}

Our second aim was to investigate the altered $\mathrm{Ca}^{2+}$ handling of cardiac myocytes in a diabetic animal model, with special emphasis on possible contribution of NCX to altered $\mathrm{Ca}^{2+}$ handling during the disease process. Isolated diastolic dysfunction is observed in almost half of otherwise asymptomatic patients with well-controlled diabetes and thus may precede diastolic heart failure. Since the mechanisms underlying diastolic dysfunction observed in diabetic patients are not well understood, we tested the hypothesis that diastolic dysfunction may be associated with impaired myocardial $\mathrm{Ca}^{2+}$ handling, $\mathrm{NCX}$ and/or SERCA function in an animal model of type 1 diabetes.

Earlier studies have shown that in isolated ventricular myocytes, diabetes resulted in a significant prolongation of action potential duration compared with controls, with after depolarizations occurring in diabetic myocytes [48]. Sustained outward $\mathrm{K}^{+}$current and peak outward component of the inward rectifier current were reduced in diabetic myocytes, while $\mathrm{I}_{\mathrm{to}}$ was increased. It is important to note that there was no significant change in L-type $\mathrm{Ca}^{2+}$ current. As $\mathrm{L}$ type $\mathrm{Ca}^{2+}$ current is a major component in $\mathrm{Ca}^{2+}$ cycling, this fact helps to interpret the changes in the $\mathrm{Ca}^{2+}$ handling that we observed as a consequence of diabetes. Thus, our goal was to characterize the cellular events associated with diastolic dysfunction in 
experimental diabetes mellitus and to explore what role NCX may play in these pathological circumstances.

We were able to reproduce characteristic diabetic alterations, including increased diastolic $\mathrm{Ca}^{2+}$ levels (Fig 7) as manifestation of diastolic dysfunction, and reduced cell shortening. However, despite of the obvious signs of disturbed $\mathrm{Ca}^{2+}$ handling, the differences between the diabetic and healty cells were not very pronounced in our experiments. Obviously, this is a major limitation of the diabetes model we used, emphasizing the need for development of better experimental models and further extensive research in this field. Interestingly, in our rabbit model, at least at this stage of disease, the loss of contractile force was not associated with reduced intracellular $\mathrm{Ca}^{2+}$ transient. The increased $\mathrm{Ca}^{2+}$ transient seen in our experiments probably reflects a compensatory mechanism that helps to maintain cellular contractility. Alternatively, decrease of the $\mathrm{Ca}^{2+}$ sensitivity of the contractile machinery can also occur as a primary alteration during the disease process.

As one of the most characteristic change in diabetic cells, we found that relaxation of the $\mathrm{Ca}^{2+}$ transient was prolonged, which is in line with previous observations suggesting a diminished SERCA function as a consequence of diabetes. Inhibition of NCX by application of SEA0400 further prolonged the $\mathrm{Ca}^{2+}$ transient in diabetic, but not in normal cells, suggesting an increased role for NCX in the maintenance of $\mathrm{Ca}^{2+}$ homeostasis in diabetic cells. This is also supported by our other finding that SEA0400 increased the $\mathrm{Ca}^{2+}$ transient in the diabetic cells, but not in normal cells, indicating that diabetic cells are more sensitive to any perturbation of the $\mathrm{Ca}^{2+}$ cycling. On the other hand, SEA0400 also increased the contractile force in the diabetic cells, which may suggest a potential therapeutic possibility for NCX inhibition.

A difficult point in our results is the increased contractility observed in normal cells in response to SEA0400, which was apparently independent of the intracellular $\mathrm{Ca}^{2+}$ transient. It is very hard to interpret this finding, because it is generally accepted that in normal healthy myocytes the increase of the contractile force should be, at least in part, the consequence of the elevated $\mathrm{Ca}^{2+}$ transient. Although increased sensitivity of the contractile machinery to $\mathrm{Ca}^{2+}$ could be a possible explanation, it is hard to assume that this would occur following partial inhibition of NCX. A possible, though rather speculative explanation is that inhibition of NCX can also affect the local submembrane $\mathrm{Ca}^{2+}$ levels $\left(\left[\mathrm{Ca}^{2+}\right]_{\mathrm{sm}}\right)$, which could in turn influence membrane bound enzyme systems involved in signaling cascades, leading to altered $\mathrm{Ca}^{2+}$ sensitivity of the contractile system. A possible role for such local $\left[\mathrm{Ca}^{2+}\right]_{\mathrm{sm}}$ changes in 
the regulation of cell physiology emphasizes the need for the development of novel methodology to detect $\mathrm{Ca}^{2+}$ in specific subcellular compartments.

\subsubsection{Rest decay experiments}

Kinetics of the development of the steady state conditions in the $\mathrm{Ca}^{2+}$ handling after a period of rest can also provide valuable insights into the altered $\mathrm{Ca}^{2+}$ handling in diabetes. Cardiac myocytes from different species can behave differently in this test, results depend on the actual balance between the trans-sarcolemmal and SR $\mathrm{Ca}^{2+}$ fluxes. Alterations associated with different pathological situations can also affect the equilibrium between these $\mathrm{Ca}^{2+}$ routes at rest. Indeed, we found that diabetic cells showed a slower time course of $\mathrm{Ca}^{2+}$ refilling kinetics. This occurs in spite of no change in $\mathrm{I}_{\mathrm{CaL}}$, which is the main source of $\mathrm{Ca}^{2+}$ under these conditions, suggesting that either the reverse-mode NCX and/or the SERCA function is hampered in the diabetic cells.

Regarding the effect of NCX inhibition on the recovery of $\mathrm{Ca}^{2+}$ transient after resting period, we found an interesting difference between the behavior of first and final part of the curve in the normal and diabetic cells. Theoretically, the final $\mathrm{Ca}^{2+}$ load during this protocol depends on the relative magnitude of $\mathrm{Ca}^{2+}$ fluxes via SERCA and forward NCX. Inhibition of NCX would favour the SR $\mathrm{Ca}^{2+}$ refilling through SERCA, which would result in increased $\mathrm{Ca}^{2+}$ load of the SR and would lead to elevated $\mathrm{Ca}^{2+}$ transient. However, our measurements show that the $\mathrm{Ca}^{2+}$ load of the cell becomes lower after NCX inhibition in both groups, suggesting a more complex scenario during this protocol. An obvious explanation for this phenomenon would be the involvement of the reverse-mode NCX in the refilling of the cell with $\mathrm{Ca}^{2+}$, which is also blocked by SEA0400. The validation of this hypothesis, however, would require a more thorough investigation. The lower $\mathrm{Ca}^{2+}$ transient amplitude at the end of the protocol in the presence of SEA0400 can also be ascribed to the concomitant inhibition of $\mathrm{I}_{\mathrm{CaL}}$ [41], because of which the final steady state occurs at lower level of cell $\mathrm{Ca}^{2+}$ content.

The first part of the curve, however, shows different behavior, with a lower $\mathrm{Ca}^{2+}$ transient in the diabetic group. A reasonable, although speculative interpretation can be that inhibition of a certain percentage of NCX reveals an already hampered NCX function in diabetic cells, which results in slower $\mathrm{Ca}^{2+}$ refilling. This explanation implies again that reverse NCX may play a role in the beginning of the refilling process. Indeed, the reverse NCX is allowed to work and carry $\mathrm{Ca}^{2+}$ into the cell during the first part of the action potential (see Fig 1), but only when the local subsarcolemmal $\mathrm{Ca}^{2+}$ is low, a condition that can be met in case of smaller $\mathrm{Ca}^{2+}$ transient at the beginning of the curve. Whether this occurs in our case however, 
would require a more direct experimental support by measuring subsarcolemmal $\mathrm{Ca}^{2+}$ and its impact on $\mathrm{Ca}^{2+}$ refilling kinetics.

Another interesting point that we observed in this protocol is that compared to the effect seen in $\left(\right.$ Fig 8,9) the $\mathrm{Ca}^{2+}$ transient amplitude in the diabetic group changed in the opposite direction after application of SEA0400. These findings may suggest the differing role of NCX in the beat-to beat $\mathrm{Ca}^{2+}$ cycle at steady state conditions and during the adaptive changes of the $\mathrm{Ca}^{2+}$ handling like in this refilling protocol.

\subsection{Delivery of troponeon to cultured cardiomyocytes}

The past decade has witnessed an explosive progress of virus-based gene delivery technologies. The reason for this is that, albeit traditional approaches, such as calcium phosphate precipitation, electroporation, or liposome-mediated gene transfer perform excellently in immortalized cells of various origins, they mostly fail in primary cultured cells and under in vivo conditions. Viruses had to evolve several means for effective infection of cells that can be employed by utilizing viruses as vectors for delivering exogenous genes to the desired cells. Virus-mediated gene transfer methods have also become applicable experimental tools in cardiovascular research. In this thesis we summarize the advantages and pitfalls of a variety of $\mathrm{Ca}^{2+}$ indicators used in some optical technique employed for measuring intracellular $\mathrm{Ca}^{2+}$ levels. Recent advances of transgenesis and gene targeting technologies have heralded a new era of studies in cellular physiology to study molecular function using genetically engineered animal models and genetically encoding vector-based gene transfer systems. Several transgenic and gene-targeted models have been generated for the overexpression [49, 50], and genetic ablation of key proteins [51,52] governing cardiac structure and function. At present, however, in spite of the permanent improvements, techniques for introducing foreign genes to cultured adult cardiomyocytes suffer from substantial limitations, such as relatively low infection efficacy and/or cell surviving rate for the integration of transgenes be delivered [53, 54]. In addition, a number of studies demonstrated that vector associated cytotoxic effects directly affect a number of (electro) physiological properties of the cells [24].

Transfering foreign genes to cardiac cells of living animals is a feasible technique in several animal models; however, performing electrophysiological measurements in vivo is not easy, therefore usually in vitro electrophysiological techniques are used in cultured cells for this purpose. Similar experiments were performed in a recently published work using cultured human atrial myocytes [55] and myocytes isolated from rat, a species from which producing 
long term cell culture is much easier. Gene transfer to cardiac myocytes has been traditionally carried out in neonatal cells. However, these cells undergo differentiation, and as a result, this model is inappropriate for certain experiments since differentiating cells have ionic currents different from those in adult cells. Therefore, in vitro transducing of isolated cardiac myocytes can be a useful alternative for investigations of cardiovascular cell physiology and diseases.

Small rodents (such as mouse, rat) are far not ideal for modelling human cardiac diseases like heart failure, myocardial infarction and arrhythmia, since the small rodent heart has distinctly different action potential waveform due to its differing underlying ionic currents [56]. Therefore, in our third study we opted for a canine model, since the dog unlike the mouse and rat models is known to have characteristic action potentials and ionic current similar to those in human [57].

For testing the possible effects of viral infection the transient outward potassium current was chosen because $I_{\text {to }}$ is a relatively large current, and is present in all cells. Also, it can be relatively easily measured. The $\mathrm{I}_{\text {to }}$ gene structure is rather complex. The $\mathrm{I}_{\text {to }}$ current in canine myocytes resembles human myocytes and has a large conducting pore forming unit $\mathrm{Kv} 4.3$ connected with several auxiliary subunits such as KChIP2, KCNE2 and DPPX [58]. Structural changes during culturing ventricular myocytes were also studied [59, 60]. These changes are associated with culturing procedure associated effects, which may change a number of physiological properties of the cells in culture. Therefore, some possible alterations in $\mathrm{Ca}^{2+}$ handling and sarcolemmal ionic currents may have been diminished in cultured cells.

In our study we demonstrated that pseudorabies virus vectors can effectively transduce cultured dog cardiomyocytes. The transferred foreign gene (troponeon) could be detected as early as 16 hours following infection and up to at least four days post-infection. Furthermore, we have shown that infected cardiomyocytes well tolerate the presence of PRV vector, since their electrophysiological properties were not fundamentally changed following the infection. Also, the survival of the cells suitable for electrophysiological studies was high enough even after 4 days, proving that the virus entering the cells did not cause any observable cytotoxic effects; moreover, infected cells displayed largely unaltered electrophysiological properties. This was analyzed by 1) measuring the properties of a specific transmembrane ionic current, the transient outward current $\left(\mathrm{I}_{\mathrm{to}}\right)$, which is known to be ubiquitously present in all ventricular myocytes; 2) analyzing the intracellular $\mathrm{Ca}^{2+}$ transient. And verified by FRET measurement the transferred troponeon gene was fully functional. In our study the virus did not affect the $\mathrm{I}_{\text {to }}$ current (Fig 17). $\mathrm{I}_{\text {to }}$ was present in all cells even after 72 hours of viral infection, and neither its density nor its kinetics were significantly different from those observed in control cells 
(Fig 4). In addition we found that the kinetics of intracellular $\mathrm{Ca}^{2+}$ transient was neither significantly different between infected and non-infected cells (Fig 5, 6).

Interestingly, infected myocytes had a lower rate of physiological degradation than noninfected control cells. One possible explanation for this unexpected result is that the delayed apoptosis that may occur in cultured adult cardiomyocytes was further delayed by the viral infection probably through inactivation of the caspase system [61]. Recent studies have suggested that the latency-associated transcript (LAT) region of herpes simplex virus type 1 (HSV-1) is effective at blocking virus-induced apoptosis in vitro in various cell types [62, 63]. Alternatively, it is also possible that $\mathrm{Ca}^{2+}$ depletion due to the overexpression of a $\mathrm{Ca}^{2+}$ binding protein (troponeon) resulted in lower cytoplasmic free $\mathrm{Ca}^{2+}$ concentrations, which may have anti-apoptotic effects [64]. 


\section{CONCLUSIONS AND FUTURE PERSPECTIVES}

In conclusion, using our animal model of type I diabetes mellitus, we were able to reproduce the major characteristic alterations of the myocardial $\mathrm{Ca}^{2+}$ handling seen in diabetic patients, such as decreased force of contraction and deteriorated adaptation of the $\mathrm{Ca}^{2+}$ cycling in different experimental circumstances. Regarding the underlying mechanisms, we could demonstrate that, depending on the specific circumstances, the decreased SERCA and/or NCX function can play a significant role in these alterations. The moderate alterations that we generally saw in this model belong to the limitations of our study, together with the imperfection of the pharmacological NCX inhibition. Concerning this latter point, however, we demonstrated that SEA0400, the most widely used NCX inhibitor, can be applied when the experimental purpose does not require full NCX blockade. In many cases interpretation of our results invokes careful speculations, which underlines the need of development of more sophisticated $\mathrm{Ca}^{2+}$ imaging techniques, with which we can address more specific problems in the $\mathrm{Ca}^{2+}$ handling research. As a first step in this direction, we developed and tested a viral vector based gene delivery system that can be a useful tool in studying localized $\mathrm{Ca}^{2+}$ signals and other subcellular events or introduce siRNA for silencing ionic channel subunits underlying transmembrane ionic currents, helping to understand disease process at subcellular level in various pathological states, including diabetes. 


\section{REFERENCES}

1. Tsien, R.Y., T. Pozzan, and T.J. Rink, Calcium homeostasis in intact lymphocytes: cytoplasmic free calcium monitored with a new, intracellularly trapped fluorescent indicator. J Cell Biol, 1982. 94(2): p. 325-34.

2. Bers, D.M., Calcium cycling and signaling in cardiac myocytes. Annu Rev Physiol, 2008. 70: p. 23-49.

3. Bers, D.M., Calcium fluxes involved in control of cardiac myocyte contraction. Circ Res, 2000. 87(4): p. 275-81.

4. Bers, D.M., Cardiac excitation-contraction coupling. Nature, 2002. 415(6868): p. 198-205.

5. Bers, D.M., Cardiac Na/Ca exchange function in rabbit, mouse and man: what's the difference? J Mol Cell Cardiol, 2002. 34(4): p. 369-73.

6. $\quad$ Fein, F.S., Diabetic cardiomyopathy. Diabetes Care, 1990. 13(11): p. 1169-79.

7. Bouchard, R.A. and D. Bose, Influence of experimental diabetes on sarcoplasmic reticulum function in rat ventricular muscle. Am J Physiol, 1991. 260(2 Pt 2): p. H341-54.

8. Lagadic-Gossmann, D., et al., Altered $\mathrm{Ca}^{2+}$ handling in ventricular myocytes isolated from diabetic rats. Am J Physiol, 1996. 270(5 Pt 2): p. H1529-37.

9. Boudina, S. and E.D. Abel, Diabetic cardiomyopathy revisited. Circulation, 2007. 115(25): p. 3213-23.

10. Grynkiewicz, G., M. Poenie, and R.Y. Tsien, A new generation of $\mathrm{Ca}^{2+}$ indicators with greatly improved fluorescence properties. J Biol Chem, 1985. 260(6): p. 3440-50.

11. Minta, A., J.P. Kao, and R.Y. Tsien, Fluorescent indicators for cytosolic calcium based on rhodamine and fluorescein chromophores. J Biol Chem, 1989. 264(14): p. 8171-8.

12. Gee, K.R., et al., Chemical and physiological characterization of fluo-4 $\left.\mathrm{Ca}^{2+}\right)$ indicator dyes. Cell Calcium, 2000. 27(2): p. 97-106.

13. Paredes, R.M., et al., Chemical calcium indicators. Methods, 2008. 46(3): p. 143-51.

14. Prasher, D.C., et al., Primary structure of the Aequorea victoria green-fluorescent protein. Gene, 1992. 111(2): p. 229-33.

15. Chalfie, M., et al., Green fluorescent protein as a marker for gene expression. Science, 1994. 263(5148): p. 802-5.

16. Inouye, S. and F.I. Tsuji, Aequorea green fluorescent protein. Expression of the gene and fluorescence characteristics of the recombinant protein. FEBS Lett, 1994. 341(23): p. 277-80.

17. Miyawaki, A., et al., Fluorescent indicators for $\mathrm{Ca}^{2+}$ based on green fluorescent proteins and calmodulin. Nature, 1997. 388(6645): p. 882-7.

18. Griesbeck, O., et al., Reducing the environmental sensitivity of yellow fluorescent protein. Mechanism and applications. J Biol Chem, 2001. 276(31): p. 29188-94.

19. Miyawaki, A., et al., Dynamic and quantitative $\mathrm{Ca}^{2+}$ measurements using improved cameleons. Proc Natl Acad Sci U S A, 1999. 96(5): p. 2135-40. 
20. Heim, N. and O. Griesbeck, Genetically encoded indicators of cellular calcium dynamics based on troponin C and green fluorescent protein. J Biol Chem, 2004. 279(14): p. 14280-6.

21. Takahashi, A., et al., Measurement of intracellular calcium. Physiol Rev, 1999. 79(4): p. 1089-125.

22. Palmer, A.E. and R.Y. Tsien, Measuring calcium signaling using genetically targetable fluorescent indicators. Nat Protoc, 2006. 1(3): p. 1057-65.

23. Shuai, J. and I. Parker, Optical single-channel recording by imaging $\mathrm{Ca}^{2+}$ flux through individual ion channels: theoretical considerations and limits to resolution. Cell Calcium, 2005. 37(4): p. 283-99.

24. Melo, L.G., et al., Gene and cell-based therapies for heart disease. FASEB J, 2004. 18(6): p. 648-63.

25. Ly, H., et al., Gene therapy in the treatment of heart failure. Physiology (Bethesda), 2007. 22: p. 81-96.

26. Guzman, R.J., et al., Efficient gene transfer into myocardium by direct injection of adenovirus vectors. Circ Res, 1993. 73(6): p. 1202-7.

27. Donahue, J.K., et al., Ultrarapid, highly efficient viral gene transfer to the heart. Proc Natl Acad Sci U S A, 1997. 94(9): p. 4664-8.

28. Schulick, A.H., et al., In vivo gene transfer into injured carotid arteries. Optimization and evaluation of acute toxicity. Circulation, 1995. 91(9): p. 2407-14.

29. Poller, W., et al., Highly variable expression of virus receptors in the human cardiovascular system. Implications for cardiotropic viral infections and gene therapy. Z Kardiol, 2002. 91(12): p. 978-91.

30. Nalbantoglu, J., et al., Expression of the primary coxsackie and adenovirus receptor is downregulated during skeletal muscle maturation and limits the efficacy of adenovirus-mediated gene delivery to muscle cells. Hum Gene Ther, 1999. 10(6): p. 1009-19.

31. Maeda, Y., et al., Efficient gene transfer into cardiac myocytes using adeno-associated virus (AAV) vectors. J Mol Cell Cardiol, 1998. 30(7): p. 1341-8.

32. Du, L., et al., Differential myocardial gene delivery by recombinant serotype-specific adeno-associated viral vectors. Mol Ther, 2004. 10(3): p. 604-8.

33. Sakoda, T., et al., A high-titer lentiviral production system mediates efficient transduction of differentiated cells including beating cardiac myocytes. J Mol Cell Cardiol, 1999. 31(11): p. 2037-47.

34. Zhao, J., et al., Lentiviral vectors for delivery of genes into neonatal and adult ventricular cardiac myocytes in vitro and in vivo. Basic Res Cardiol, 2002. 97(5): p. 348-58.

35. Boldogkoi, Z., et al., Pseudorabies virus-based gene delivery to rat embryonic spinal cord grafts. Hum Gene Ther, 2002. 13(6): p. 719-29.

36. Boldogkoi, Z., et al., Novel tracing paradigms--genetically engineered herpesviruses as tools for mapping functional circuits within the CNS: present status and future prospects. Prog Neurobiol, 2004. 72(6): p. 417-45.

37. Boldogkoi, Z., et al., Genetically timed, activity-sensor and rainbow transsynaptic viral tools. Nat Methods, 2009. 
38. Lengyel, C., et al., Role of slow delayed rectifier $K^{+}$-current in QT prolongation in the alloxan-induced diabetic rabbit heart. Acta Physiol (Oxf), 2008. 192(3): p. 359-68.

39. Shimoni, Y., H.S. Ewart, and D. Severson, Type I and II models of diabetes produce different modifications of $\mathrm{K}^{+}$currents in rat heart: role of insulin. J Physiol, 1998. 507 ( Pt 2): p. 485-96.

40. Shimoni, Y., et al., Modulation of potassium currents by angiotensin and oxidative stress in cardiac cells from the diabetic rat. J Physiol, 2005. 567(Pt 1): p. 177-90.

41. Birinyi, P., et al., Effects of SEA0400 and $\mathrm{KB}-\mathrm{R} 7943$ on $\mathrm{Na}^{+} / \mathrm{Ca}^{2+}$ exchange current and L-type $\mathrm{Ca}^{2+}$ current in canine ventricular cardiomyocytes. Naunyn Schmiedebergs Arch Pharmacol, 2005. 372(1): p. 63-70.

42. Fowler, M.R., et al., Complex modulation of L-type $\left.\mathrm{Ca}^{2+}\right)$ current inactivation by sorcin in isolated rabbit cardiomyocytes. Pflugers Arch, 2009. 457(5): p. 1049-60.

43. Restrepo, J.G. and A. Karma, Spatiotemporal intracellular calcium dynamics during cardiac alternans. Chaos, 2009. 19(3): p. 037115.

44. Acsai, K., et al., Effect of partial blockade of the $\mathrm{Na}\left({ }^{+}\right) / \mathrm{Ca}\left({ }^{2+}\right)$-exchanger on $\mathrm{Ca}\left({ }^{2+}\right)$ handling in isolated rat ventricular myocytes. Eur J Pharmacol, 2007. 576(1-3): p. 1-6.

45. Farkas, A.S., et al., $\mathrm{Na}\left({ }^{+}\right) / \mathrm{Ca}\left({ }^{2+}\right)$ exchanger inhibition exerts a positive inotropic effect in the rat heart, but fails to influence the contractility of the rabbit heart. $\mathrm{Br} \mathrm{J}$ Pharmacol, 2008. 154(1): p. 93-104.

46. Ozdemir, S., et al., Pharmacological inhibition of na/ca exchange results in increased cellular $\mathrm{Ca}^{2+}$ load attributable to the predominance of forward mode block. Circ Res, 2008. 102(11): p. 1398-405.

47. Birinyi, P., et al., The $\mathrm{Na}^{+} / \mathrm{Ca}^{2+}$ exchange blocker SEA0400 fails to enhance cytosolic $\mathrm{Ca}^{2+}$ transient and contractility in canine ventricular cardiomyocytes. Cardiovasc Res, 2008. 78(3): p. 476-84.

48. Lengyel, C., et al., Diabetes mellitus attenuates the repolarization reserve in mammalian heart. Cardiovasc Res, 2007. 73(3): p. 512-20.

49. Adachi-Akahane, S., et al., Calcium signaling in transgenic mice overexpressing cardiac $\left.\mathrm{Na}^{+}{ }^{+}\right)-\mathrm{Ca}^{2+}$ exchanger. J Gen Physiol, 1997. 109(6): p. 717-29.

50. Chossat, N., et al., Adenoviral SERCAla gene transfer to adult rat ventricular myocytes induces physiological changes in calcium handling. Cardiovasc Res, 2001. 49(2): p. 288-97.

51. Pohlmann, L., et al., Cardiac myosin-binding protein $C$ is required for complete relaxation in intact myocytes. Circ Res, 2007. 101(9): p. 928-38.

52. Rinne, A., et al., Gene silencing in adult rat cardiac myocytes in vitro by adenovirusmediated RNA interference. J Muscle Res Cell Motil, 2006. 27(5-7): p. 413-21.

53. Communal, C., et al., Decreased efficiency of adenovirus-mediated gene transfer in aging cardiomyocytes. Circulation, 2003. 107(8): p. 1170-5.

54. Li, Z., et al., Adenovirus-mediated gene transfer to adult mouse cardiomyocytes is selectively influenced by culture medium. J Gene Med, 2003. 5(9): p. 765-72.

55. Liu, X., et al., Silencing GIRK4 expression in human atrial myocytes by adenovirusdelivered small hairpin RNA. Mol Biol Rep, 2009. 36(6): p. 1345-52.

56. Himmel, H.M., et al., Four different components contribute to outward current in rat ventricular myocytes. Am J Physiol, 1999. 277(1 Pt 2): p. H107-18. 
57. Jost, N., et al., Restricting excessive cardiac action potential and QT prolongation: a vital role for IKs in human ventricular muscle. Circulation, 2005. 112(10): p. 1392-9.

58. Radicke, S., et al., Functional modulation of the transient outward current Ito by KCNE beta-subunits and regional distribution in human non-failing and failing hearts. Cardiovasc Res, 2006. 71(4): p. 695-703.

59. Lipp, P., et al., Spatially non-uniform $\mathrm{Ca}^{2+}$ signals induced by the reduction of transverse tubules in citrate-loaded guinea-pig ventricular myocytes in culture. $\mathrm{J}$ Physiol, 1996. 497 ( Pt 3): p. 589-97.

60. Viero, C., et al., A primary culture system for sustained expression of a calcium sensor in preserved adult rat ventricular myocytes. Cell Calcium, 2008. 43(1): p. 59-71.

61. Communal, C., et al., Functional consequences of caspase activation in cardiac myocytes. Proc Natl Acad Sci U S A, 2002. 99(9): p. 6252-6.

62. Ahmed, M., et al., Regions of the herpes simplex virus type 1 latency-associated transcript that protect cells from apoptosis in vitro and protect neuronal cells in vivo. J Virol, 2002. 76(2): p. 717-29.

63. Inman, M., et al., Region of herpes simplex virus type 1 latency-associated transcript sufficient for wild-type spontaneous reactivation promotes cell survival in tissue culture. J Virol, 2001. 75(8): p. 3636-46.

64. Chen, X., et al., $\mathrm{Ca}^{2+}$ influx-induced sarcoplasmic reticulum $\mathrm{Ca}^{2+}$ overload causes mitochondrial-dependent apoptosis in ventricular myocytes. Circ Res, 2005. 97(10): p. 1009-17. 


\section{ACKNOWLEDGEMENTS}

I am very grateful to Professor András Varró, MD, DSc, for his continuous support and for providing me the opportunity for research at the Department of Pharmacology and Pharmacotherapy and to Professor Gyula Papp MD, DSc, academician for his criticism and helpful advice.

I am especially thankful to my supervisors András Tóth, $\mathrm{PhD}$, for his continuous support and personal guidance at the Department of Pharmacology and Pharmacotherapy and for introducing me to the fluorescent techniques. His personal guidance and helpful discussions were useful during my work and allowed me to learn the critical thinking in the scientific field. My special thanks are due to Professor Zsolt Boldogköi for his dedicated support for my first publication.

I wish to thank my grateful colleague, Károly Acsai $\mathrm{PhD}$, for his continuous support and help to study the experimental techniques in the field of the electrophysiology, and I wish to thank Balázs Ördög PhD for his many exceptionally useful help and piece of advice in my molecular works.

I would like to thank all my direct colleagues, Norbert Nagy PhD; Zoltán Márton PhD; Anita Kormos; and to Judit Szepesi for their help in my work. I am also very thankful to Zsuzsanna Sebők for her helpful technical assistance.

A particular acknowledgement goes to my parents, brother, sister, and all my friends for their help and encouragement, to whom I dedicated this $\mathrm{PhD}$ thesis. Finally, my deepest appreciation goes to my dear love, Piroska, for her love, support and encouragement in the past years. 


\section{ANNEX}

Publications related to the subject of the Thesis. 